\title{
Research Paper \\ Strategic Management Relationships With Tourism in the Age of Globalization
}

\author{
Saeed Maleki ${ }^{1}$, *Mohammad Reza Amiri Fahlyiani²
}

1. Assistant Professor, Department of Geography \& Urban Planning, Faculty of Letters and Humanities, Shahid Chamran University, Ahvaz, Iran.

2. Ph.D. Student, Department of Geography \& Urban Planning, Faculty of Letters and Humanities, Shahid Chamran University, Ahvaz, Iran.

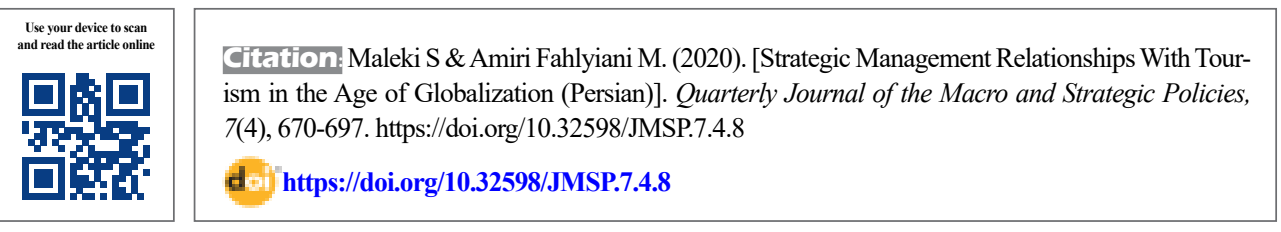

https://doi.org/10.32598/JMSP.7.4.8

Received: 31 Dec 2017

Accepted: 29 Oct 2018

Available Online: 01 Jan 202

\begin{abstract}
A B STRACT
Today in the world of tourism development, it is indisputable for strategic planning of tourism, especially for defining and existence of a development strategy for tourism. The implementation of the development strategy for tourism is determined by the functioning of strategic management in tourism. Strategic management is a proactive process of achieving long-term compatibility of the corresponding field in planned tourism environment. This management is a profitable way for implementation of priority development goals in tourism, set by the national economy, which is affected by tourism development. Strategic management basically has all the necessary features that promise efficiency and effectiveness in achieving development goals in tourism. This study emphasizes the role of strategic management in development tourism and Analysisthe current state of tourism in Iran, andPays to status of tourism in the age of globalization. And expressed that the use of strategic management can take steps to better future for the tourism industry And relying on the capacities, capabilities and current strengths, we look to the future with a better insight and building on the strengths of the tourism industry' re designed, organized and polished, The results show that tourism is essentially integrated with other economic sectors and therefore Cannot be individually taken into consideration of tourism Process with other indicators shaping the future of the world.The results suggest that to provide the government should invest in the private sector and foreign investors in developing tourism infrastructure finally, to provide guidelines for the future development of tourism.
\end{abstract}

Key words:

Globalization, Strategic management of tourism, innovation in tourism,

Sustainable tourism, Tourism marketing. 


\title{
رابطه متقابل مديريت استراتزيك با گردشَّرى در عصر جهانى شدن
}

\author{
سعيد ملكى' م، "محمدرضا اميرى فهليانى '
}

1. دانشيار، كروه جغرافيا و برنامهريزى شهرى، دانشكده ادبيات و علوم انساني دانشكاه شُهيد جمران، اهواز، ايران.

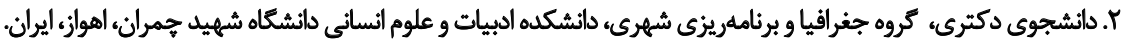

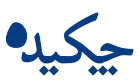

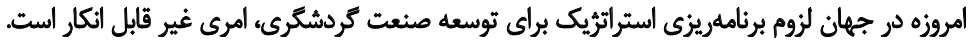

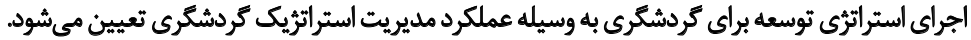

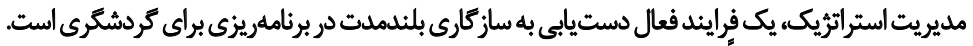

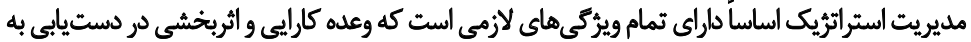

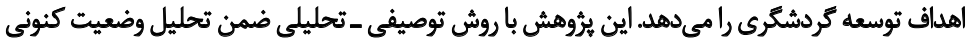

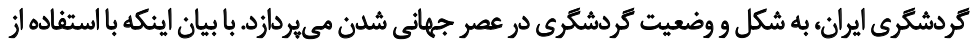

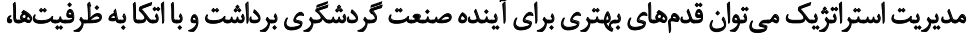

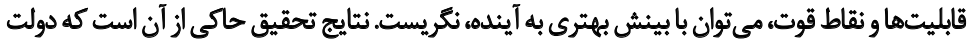

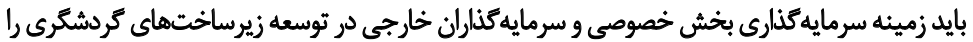

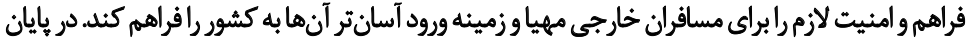

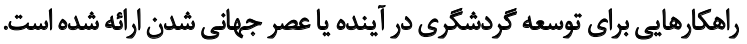

تاريخ دريافت: •ادى \&\سا تاريخ يذيرش:v • آبان

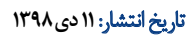

كليبوالjها:

جماني شلدن، مديريت استراتريك شئري

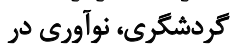

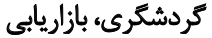
كردشكُى ايران بانئ 


\section{مقدمه}

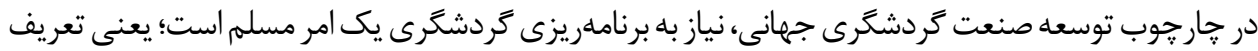

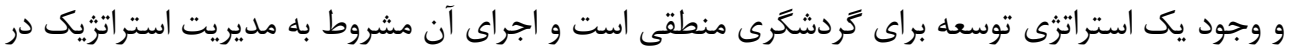

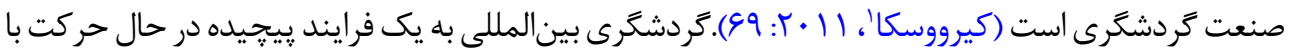

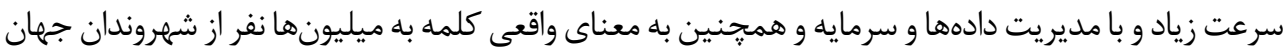

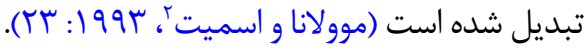

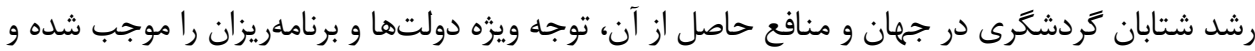

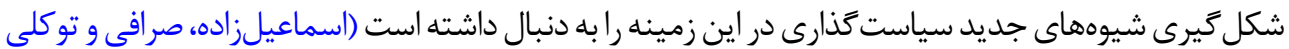

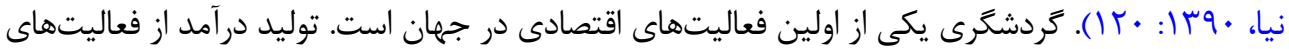

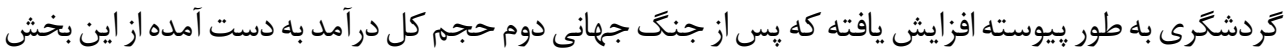

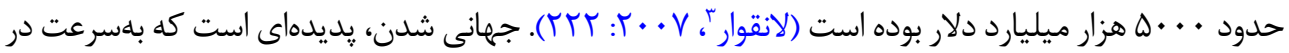

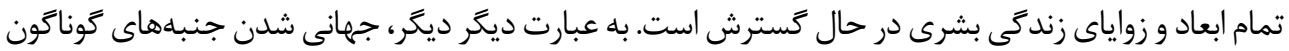

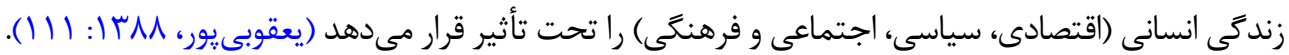

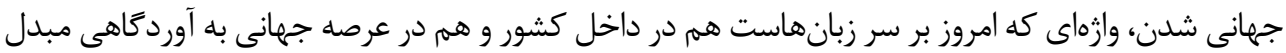

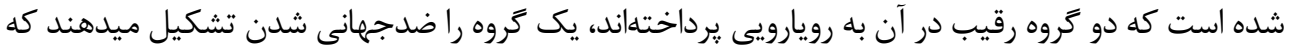

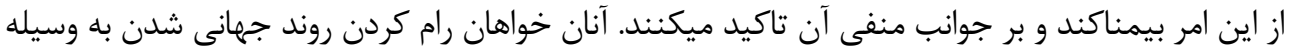

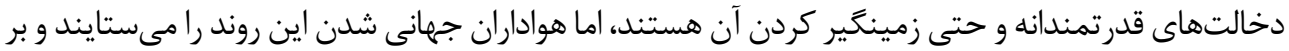

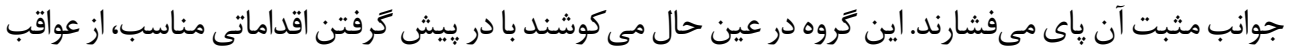

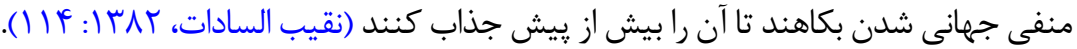

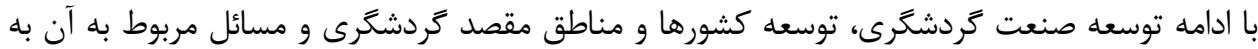

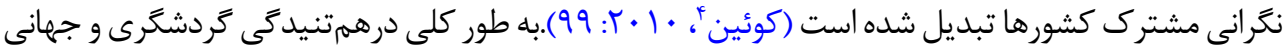

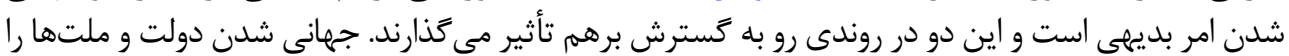

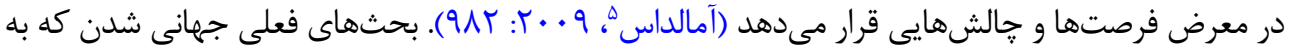

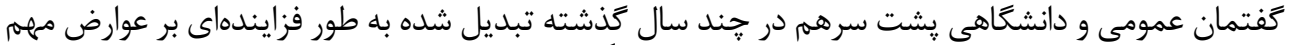

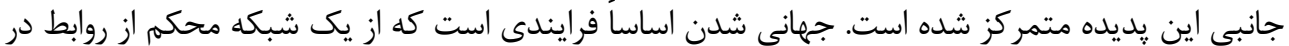

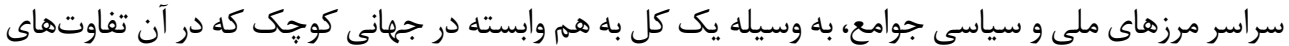

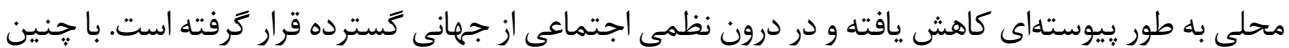

1. Kirovska

2. Mowlana \& Smith

3. Lanquar

4. Quian

5. Amaldas 


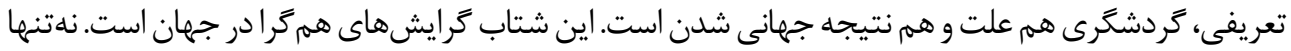

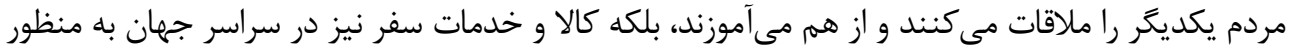

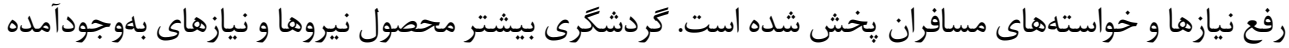

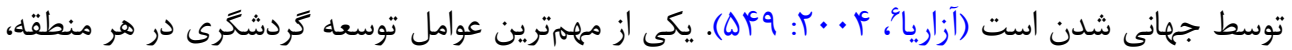

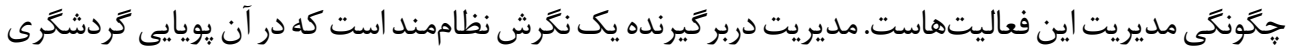

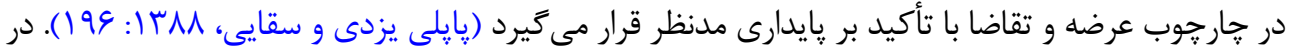

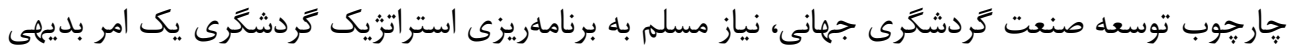

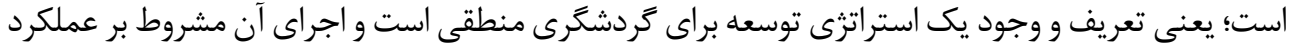

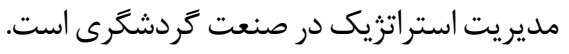

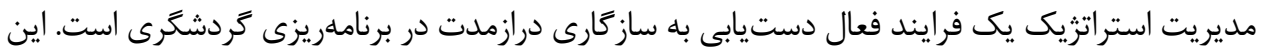

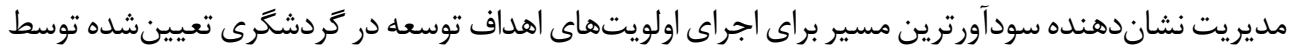

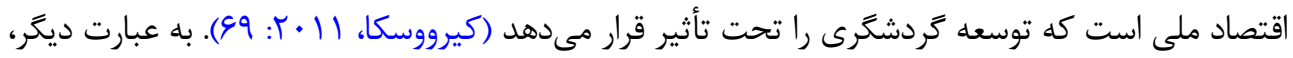

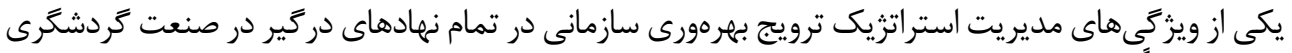

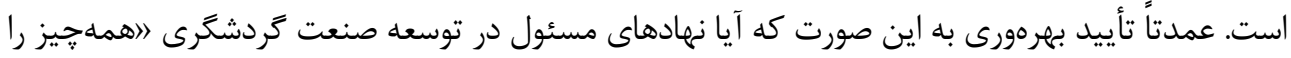

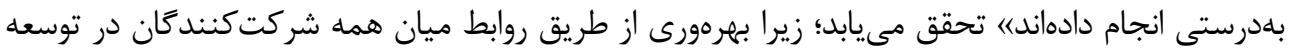

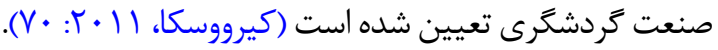

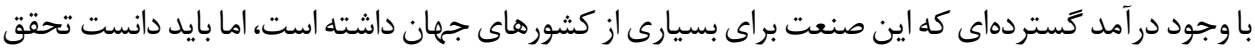

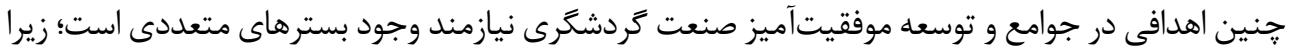

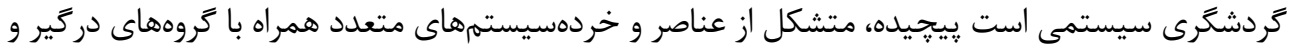

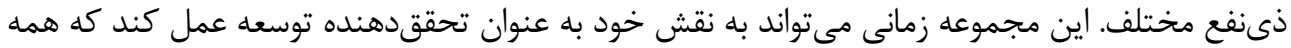

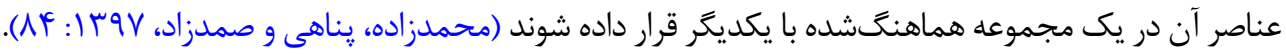

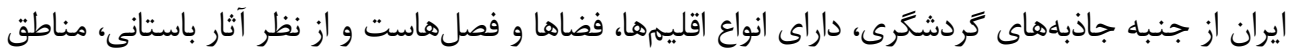

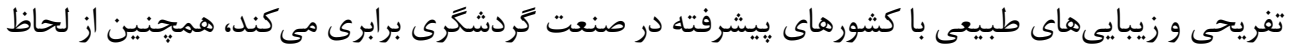

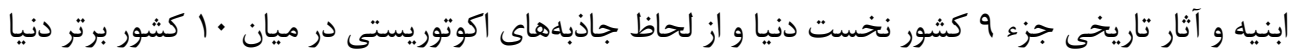

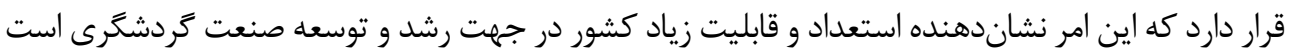

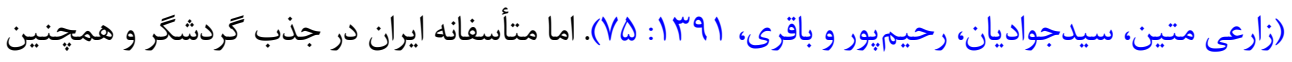

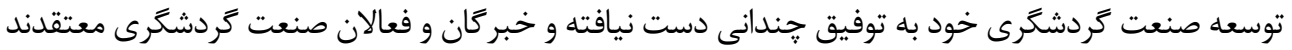

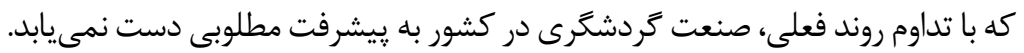

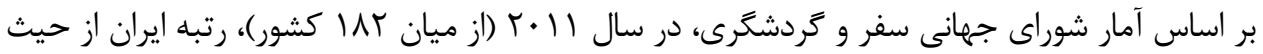

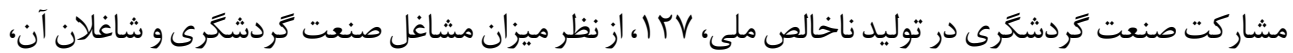

\section{Azarya}




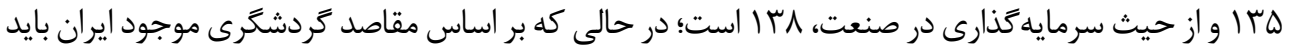

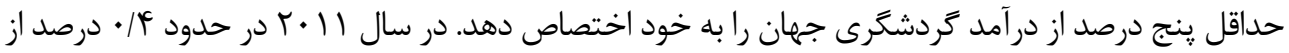

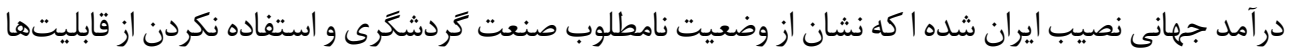

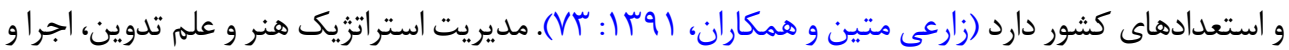

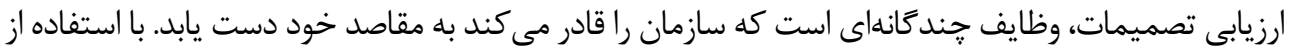

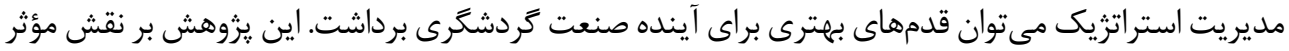

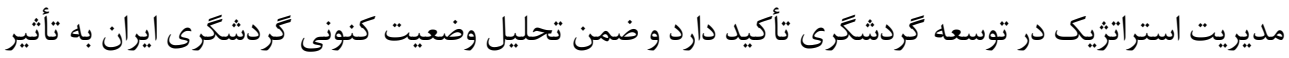

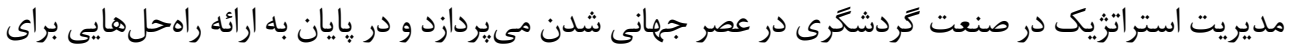

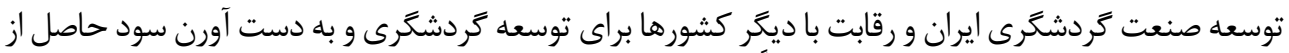

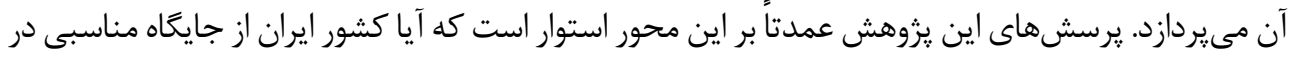

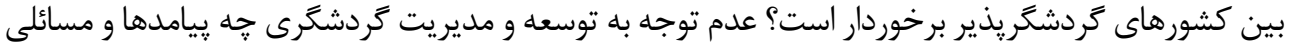

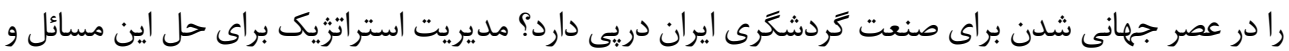

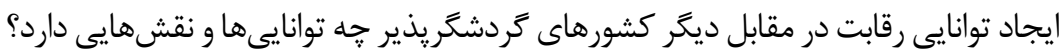

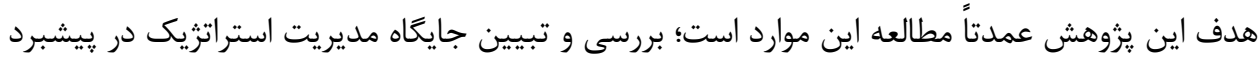

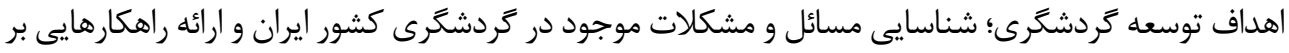

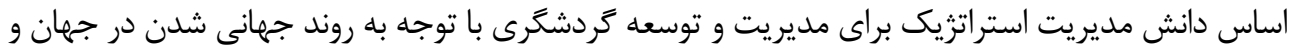

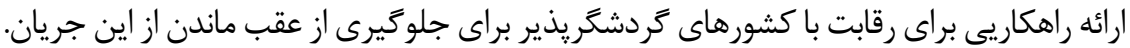

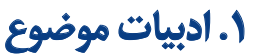

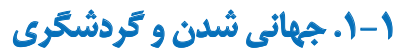

جهانى شدن افزايش وابستكى متقابل ميان كشورها، اقتصاد و مردم است. اين نهتنها شركتهاى غول آسا

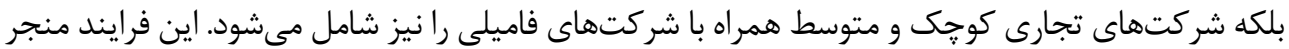

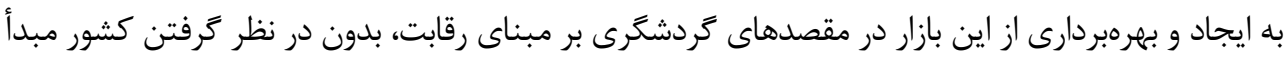

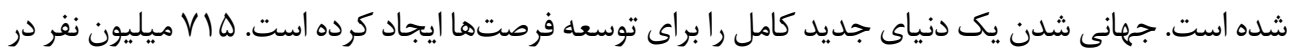

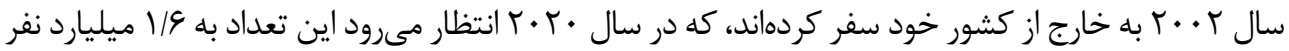

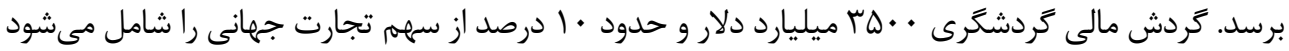

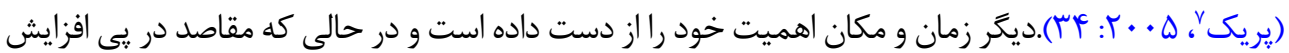

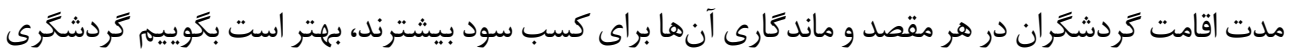

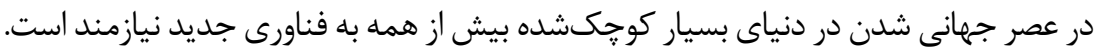




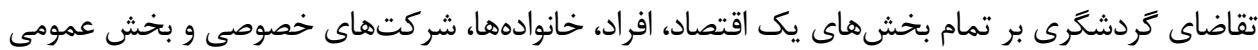

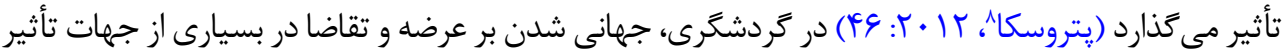

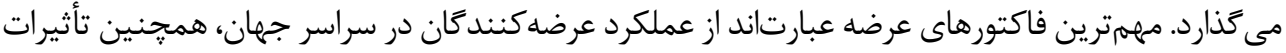

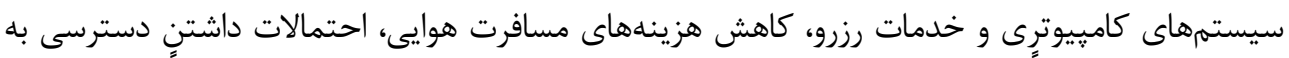

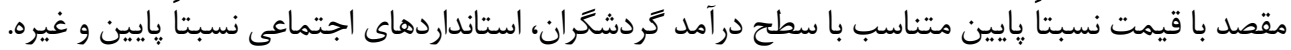

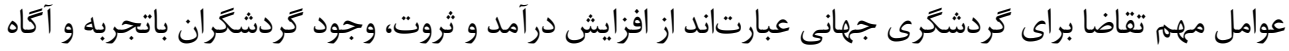

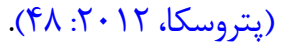

برخى از نيروهاى محر كه جهانى شدن كه تأثير روشن خود را بر صنعت گردشخرى و مسافرت مى كذارد،

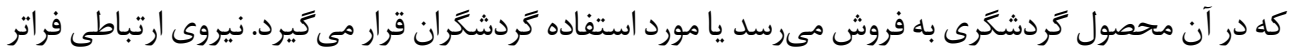

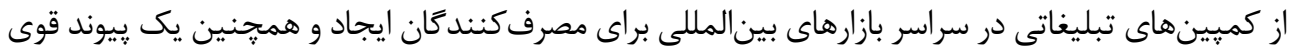

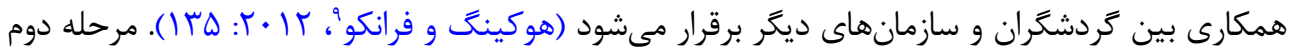

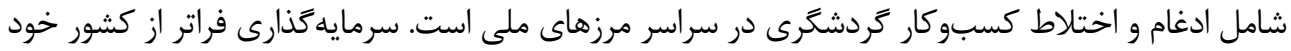

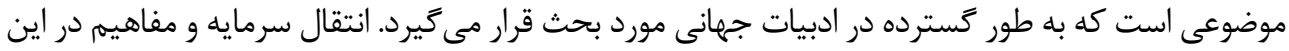

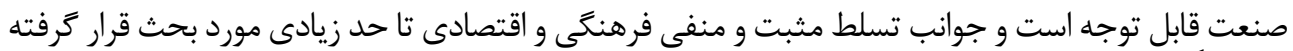

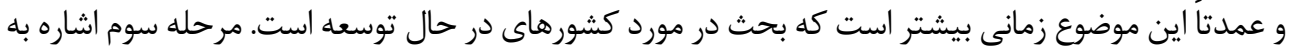

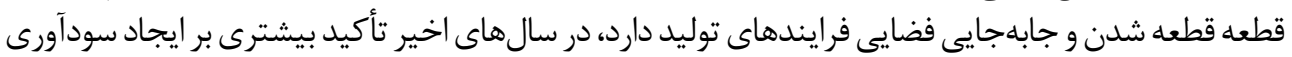

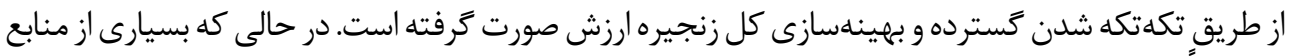

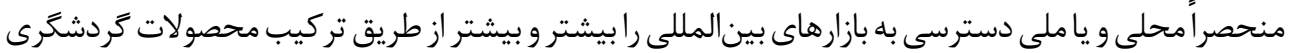

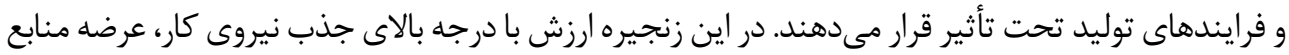

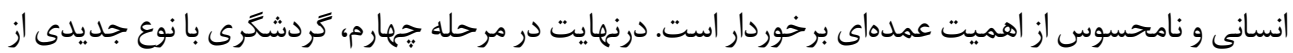

8. Petrevska

9. Hociung \& Francu

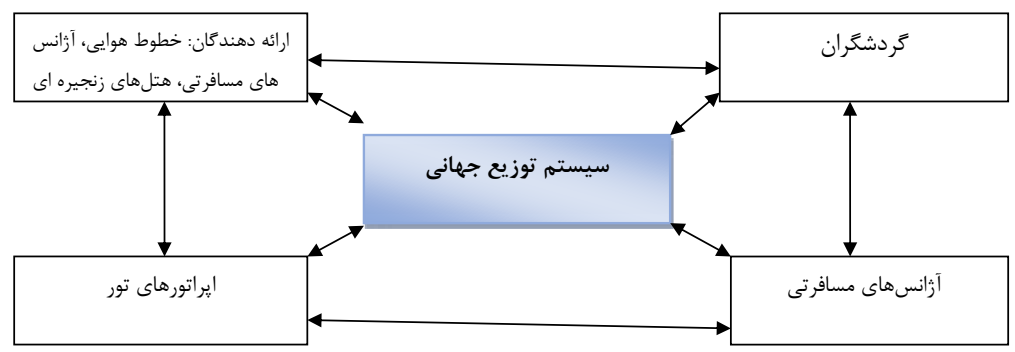

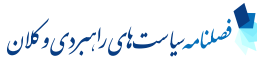

تصوير ا. سيستم توزيع جهانى كردشكرى

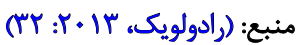


جدول ا. ويزّكى هاى جهانى شدن كردشكرى

\section{ويثركىها}

جنبها

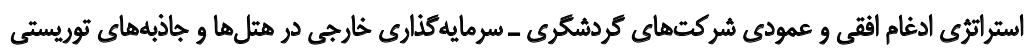

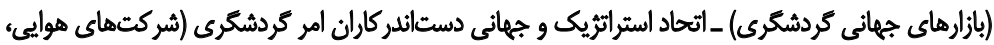

اقتصادى

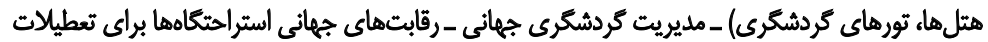

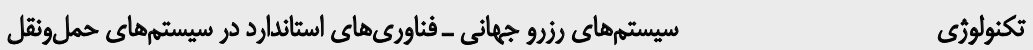

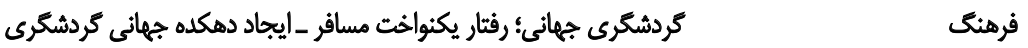

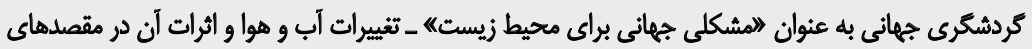

$$
\text { كردشكرى }
$$

اكولوزى

افزايش اهميت سازمانهاى جهانى كردشكرى ـ ضرورت هماهنكى و تنظيم جهانى كردش مسافران

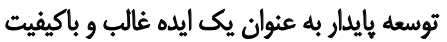

سياست

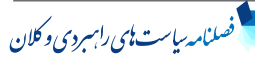

من:بع: (فيك:

بازار و مفاهيمم كسبو كار مواجه است و در عمل تمام مراحل مدل با هم هميوشى دارند.

جهانى شدن يك يديده تاريخى، اما با طبيعتى امروزى است. به طور طبيعى ريشههاى آن به اندازه كافى

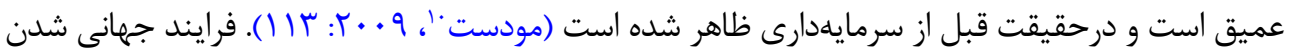

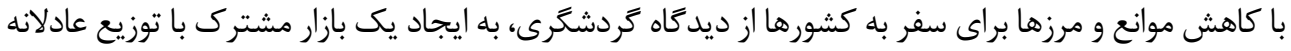

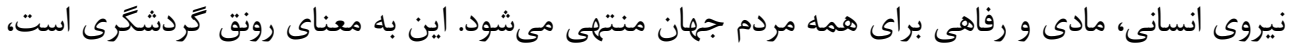

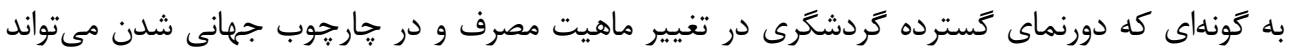

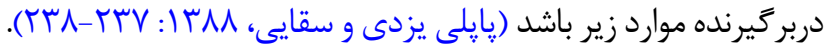

گردشگران به طور نسبى داراى توانمندى بالاى مالى هستند. البته با توجه به گستره وسيع بازار، در خرج كردن

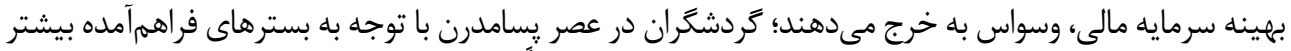

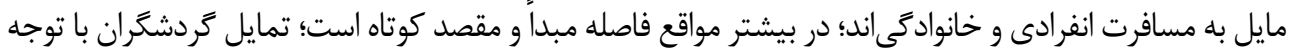

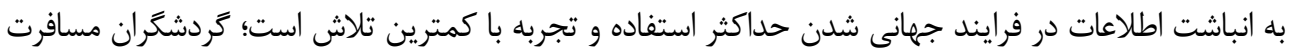

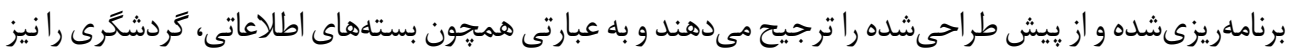

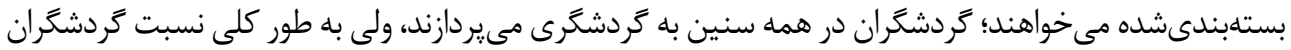

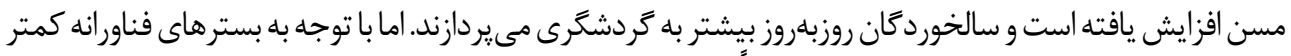

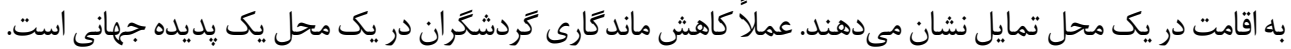

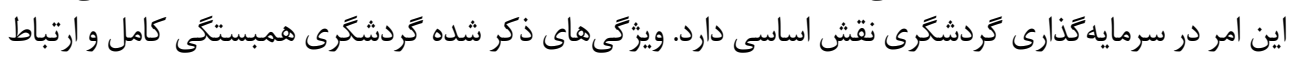

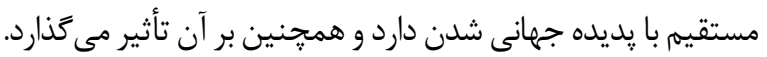

10. Modest 


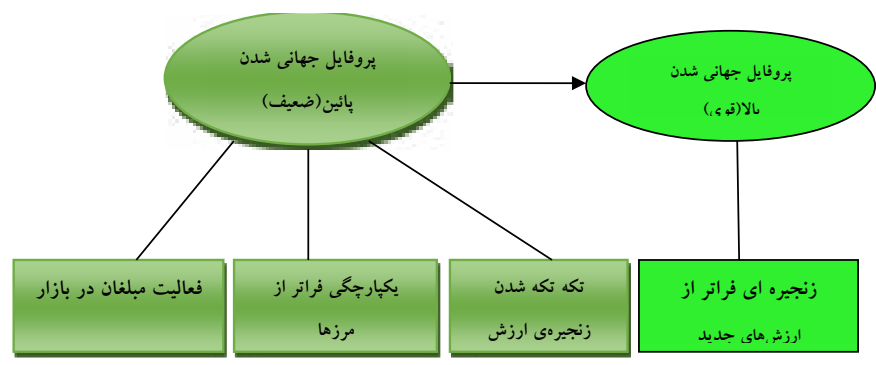

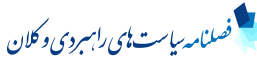

تصوير T. مراحل جهانى شدن كردشكرى

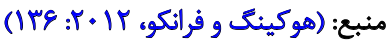

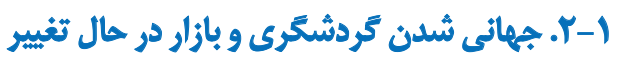

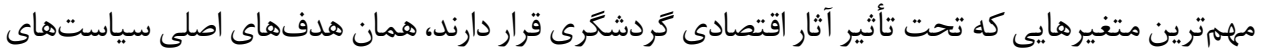

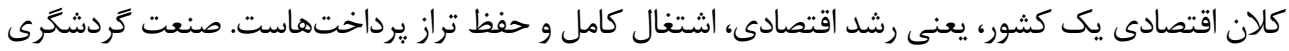

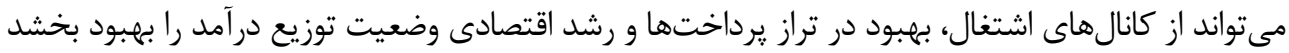

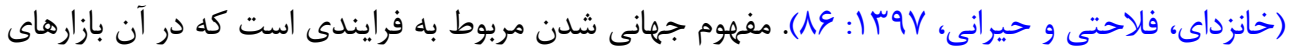

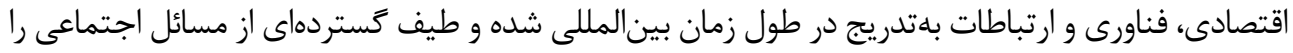

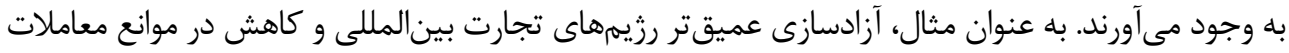

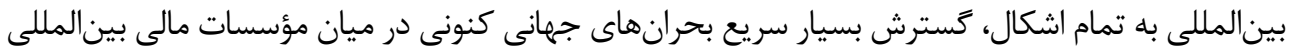

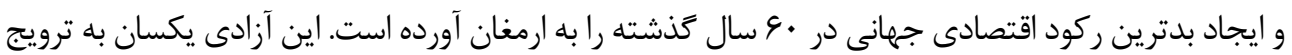

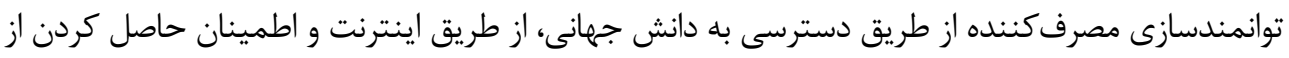

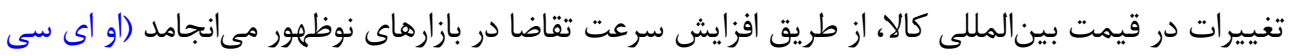

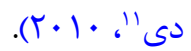

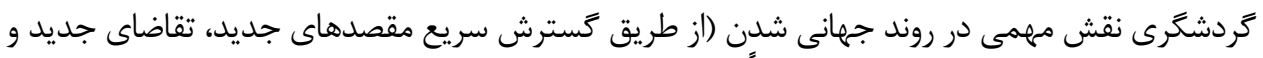

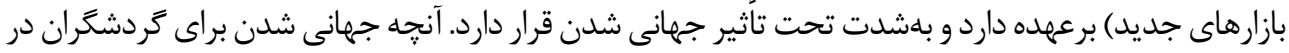

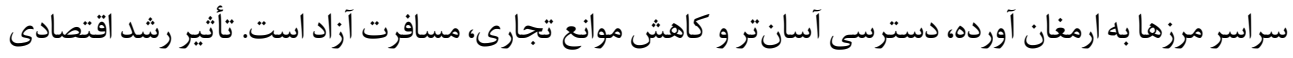

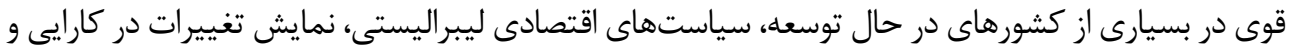

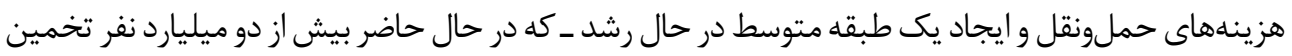

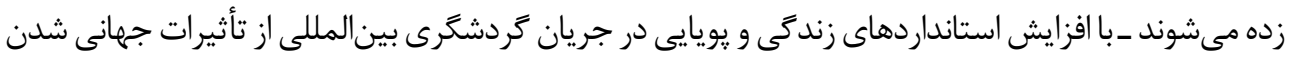

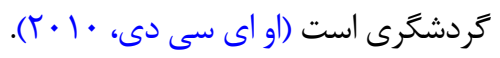




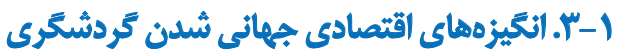

آزادسازى اقتصادى و جهانى شدن به ناجار مستلزم خطرات و مشكلاتى خواهد بود كه برخى از آنها به به طور

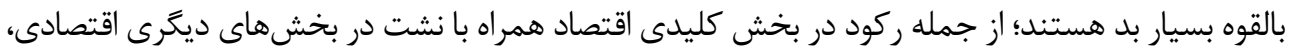

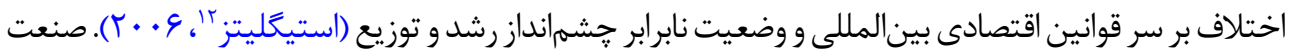

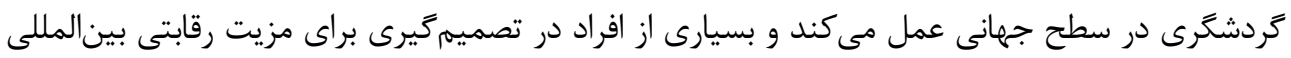

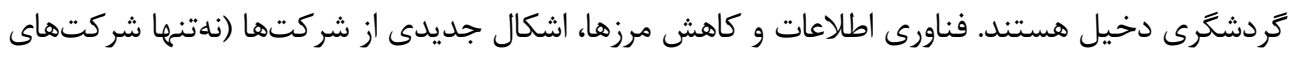

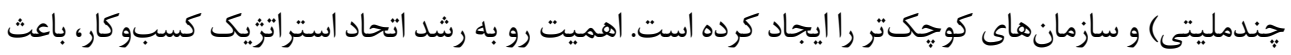

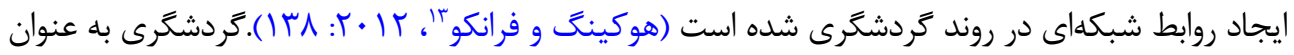

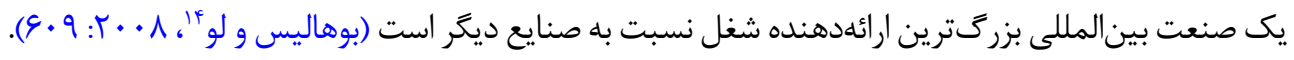

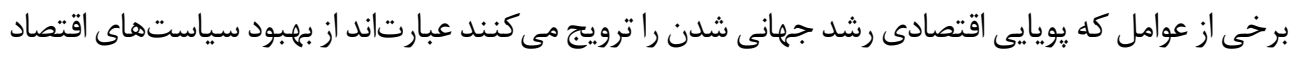

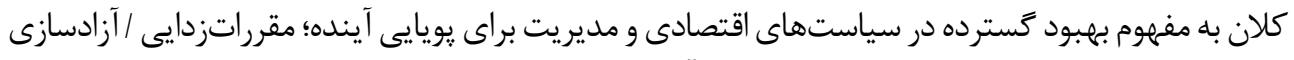

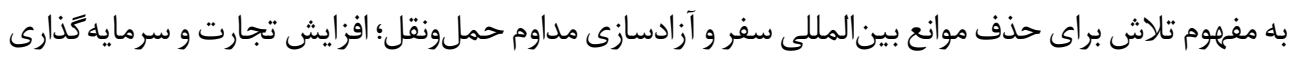

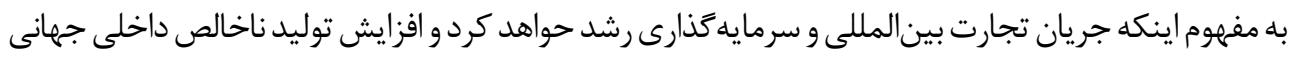

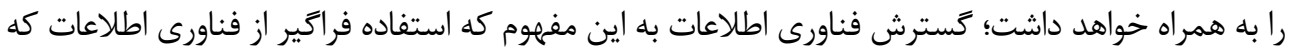

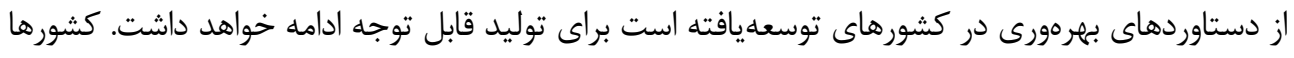

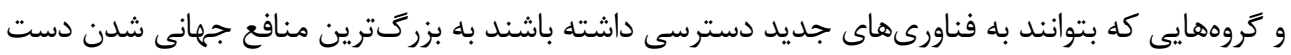

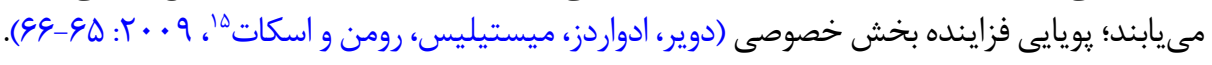

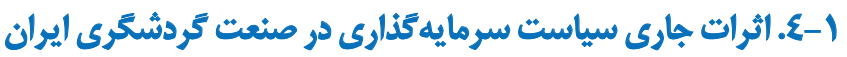

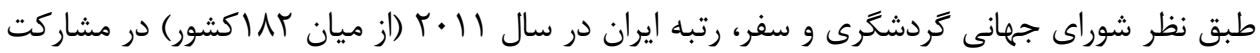

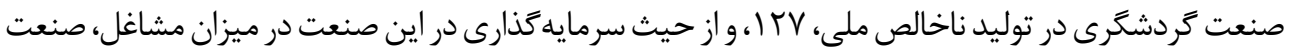

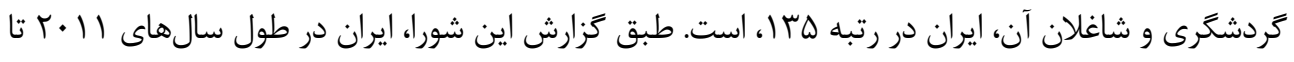

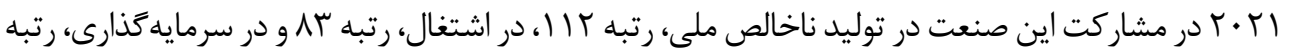

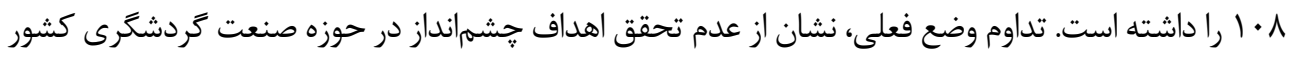

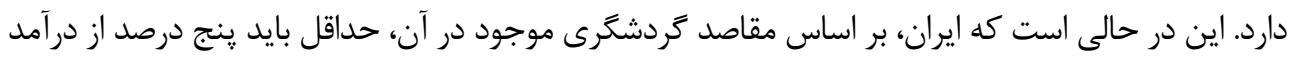

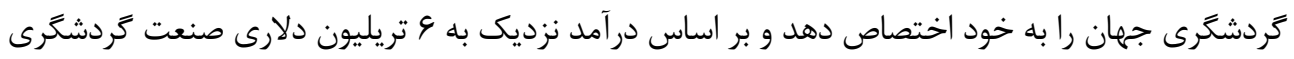

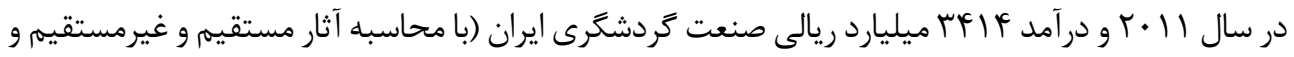

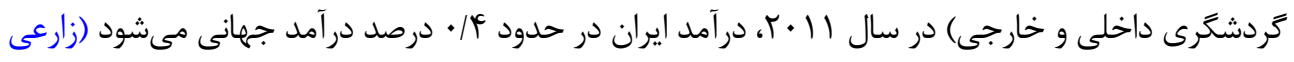

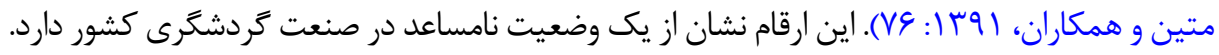

\section{Stiglitz}

13. Hociung \& Francu

14. Buhalis \& Law

15. Dwyer, Edwards, Mistilis, Roman, \& Scott 


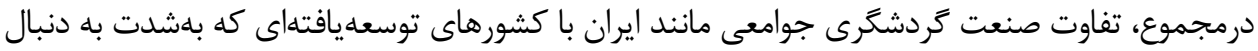

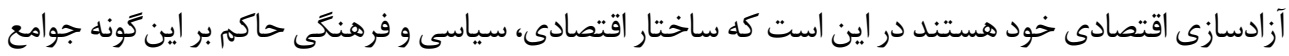

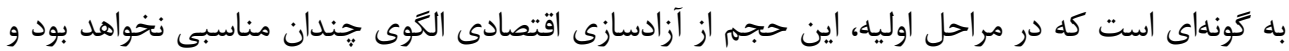

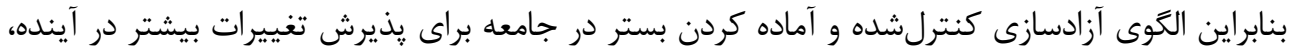

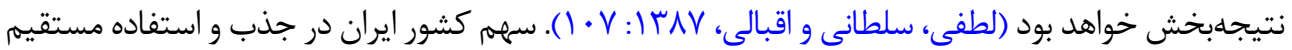

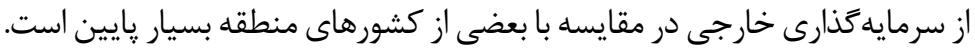

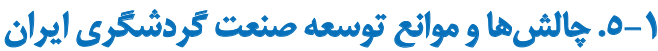

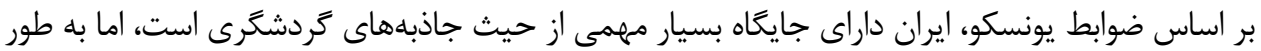

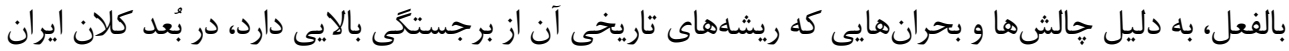

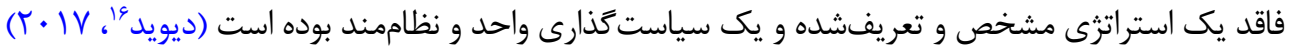

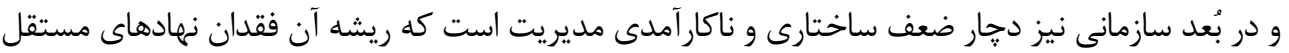

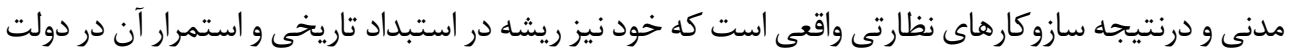

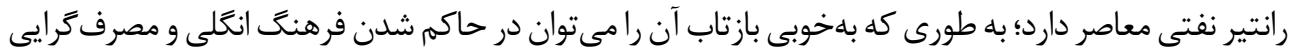

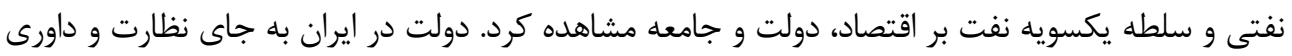

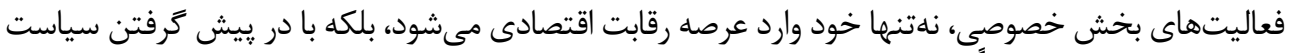

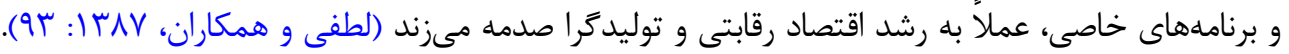

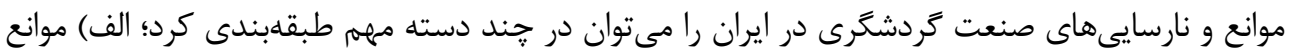

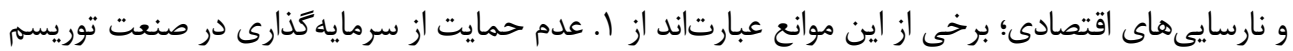

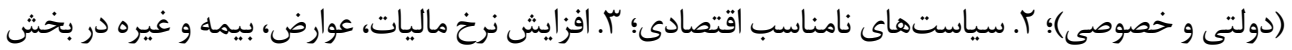

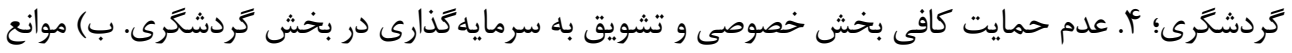

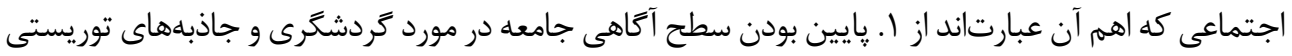

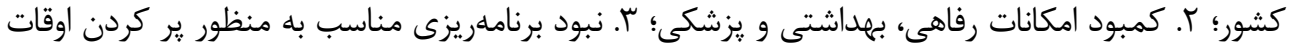

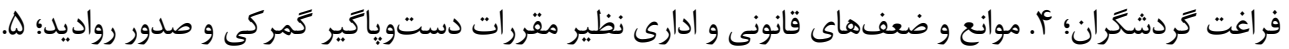

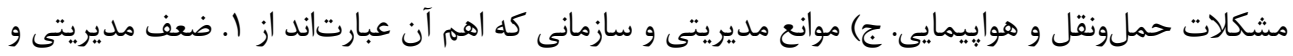

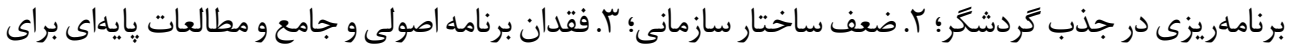

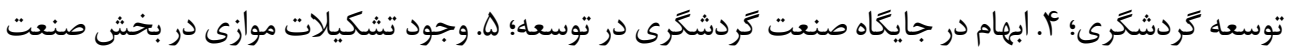

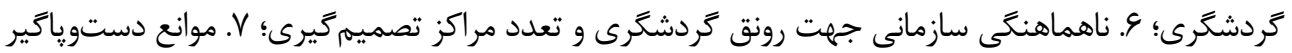

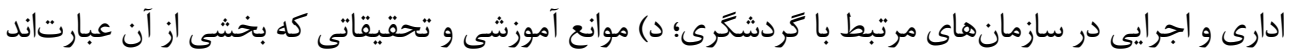

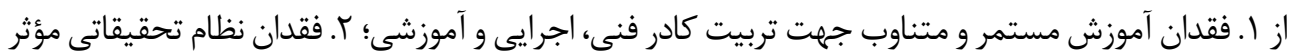

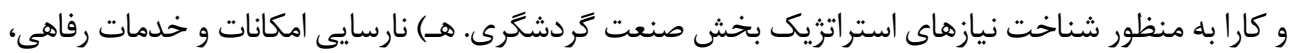

16. David 


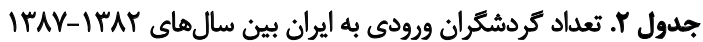

\begin{tabular}{|c|c|}
\hline تعداد كردشكران ورودى & שيال \\
\hline IHAATE & IrAY \\
\hline Iremer & IrAT \\
\hline $118 \mathrm{l} \cdot 1 \mathrm{f}$ & MHAF \\
\hline$|A| \& q \cdot \Delta$ & IrAD \\
\hline $19 Y 0194$ & IMA \\
\hline$r \cdot Y \Delta \Delta \mid A$ & IYAV \\
\hline
\end{tabular}

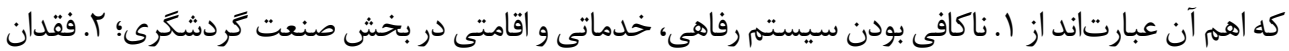

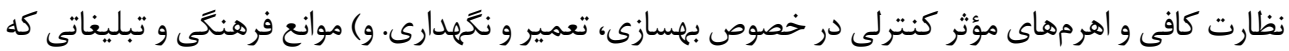

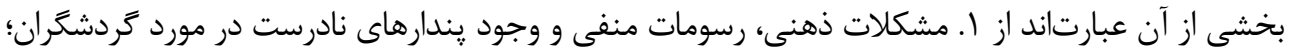

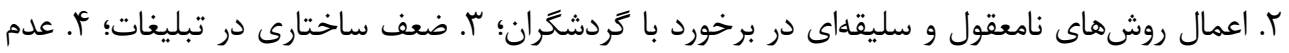

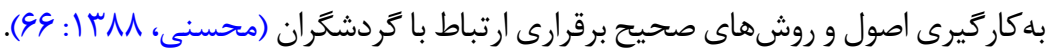

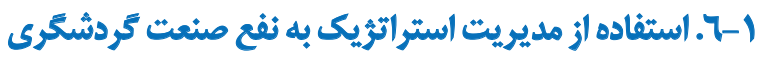

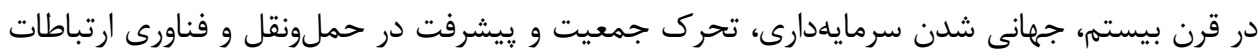

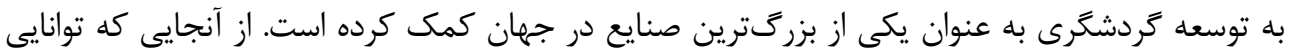

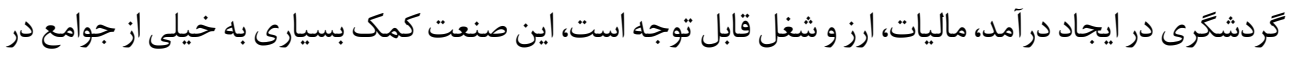

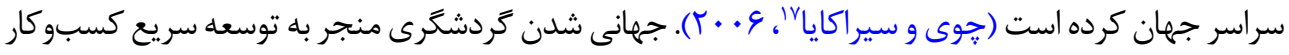

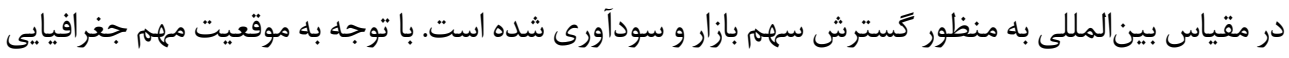

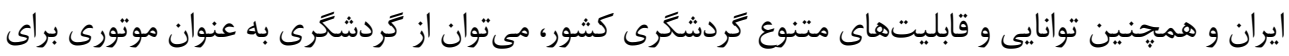
توسعه بيشتر كشور استفاده كرد.

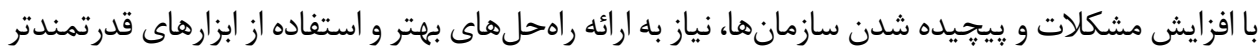

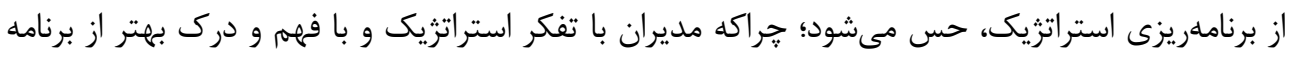

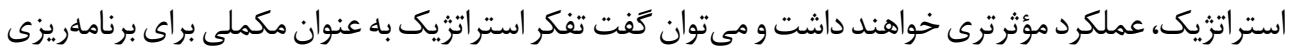

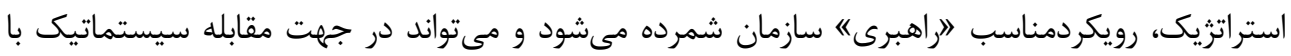

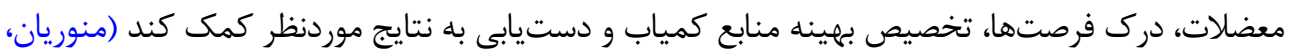




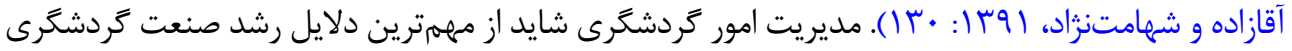

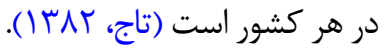

تجربيات زيادى در جهان نشان مىدهند كه هرجا گردشخَى به طور اتفاقى و بدون برنامهريزى توسعه

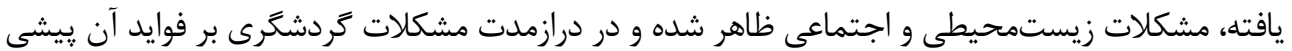

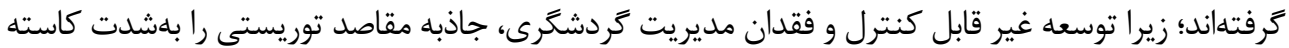

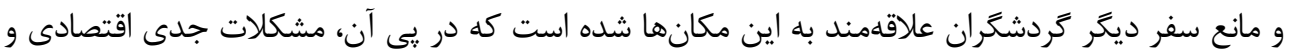

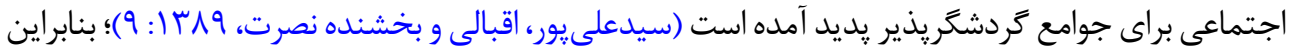

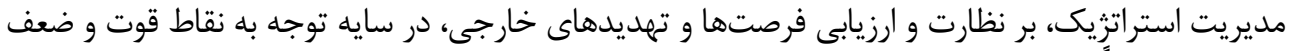

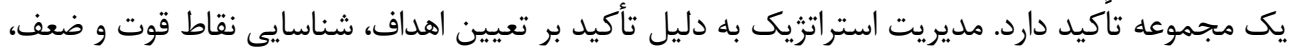

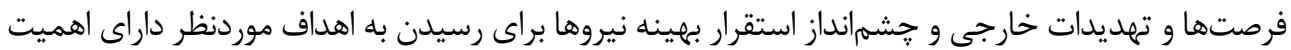

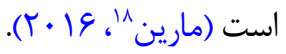

سيستمهاى برنامهريزى استراتزيك روش تدوين و اجراى تصميمات و تخصيص استراتزيك منابع لازم براى

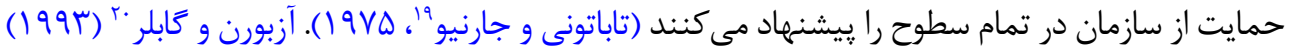

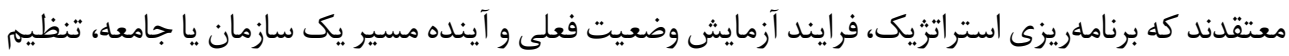

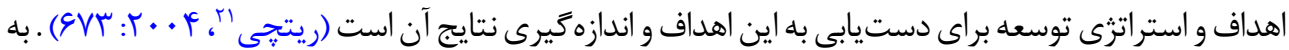

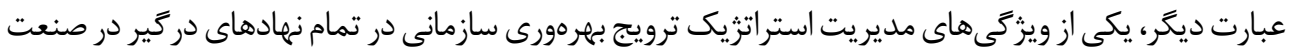

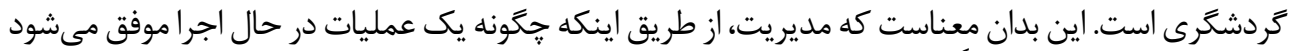

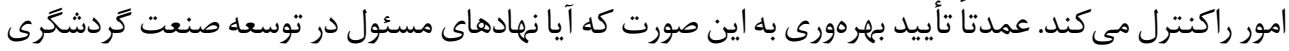

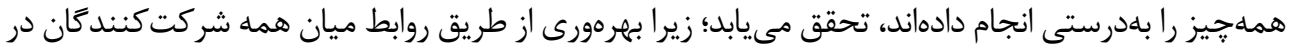

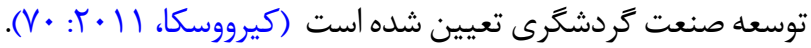

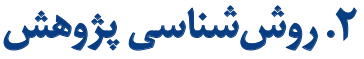

اين يزوهش از نوع كيفى است كه در جهار مرحله انجام شده است. ابتدا از طريق فيشبردارى و مطالعات

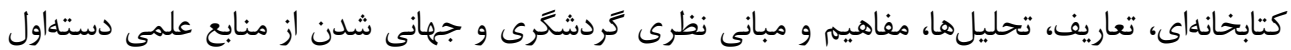

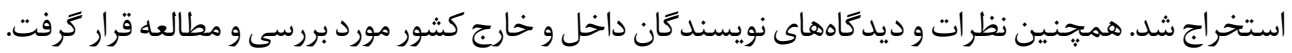

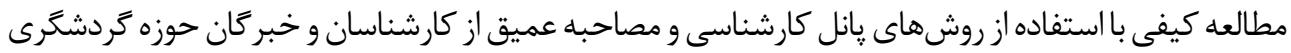

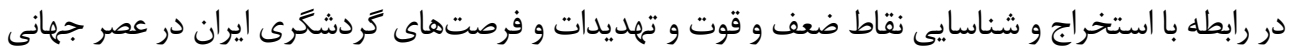

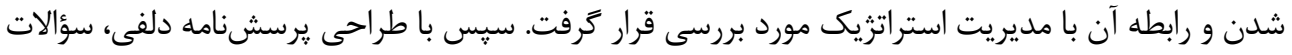

18. Marin

19. Tabatoni \& Jarniou

20. Osborne \& Gaebler

21. Ritchie 


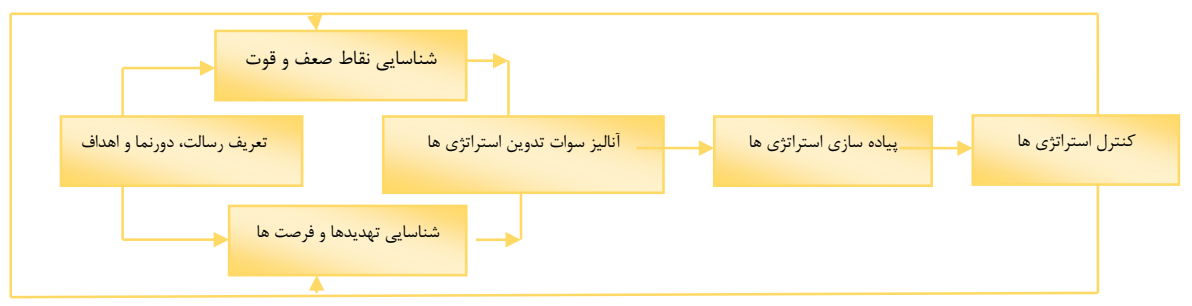

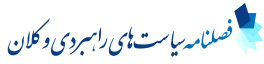

تصوير r. فرايئد مديريت استراتزيك

منبع: (محمدفام، TrAY

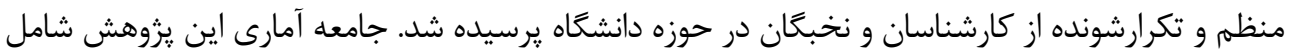

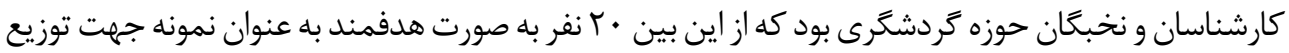

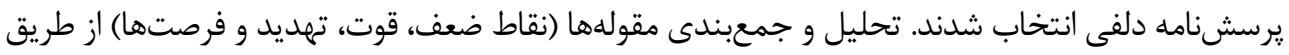

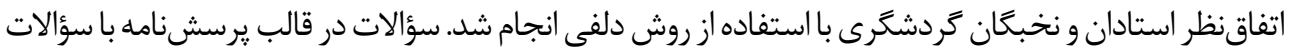

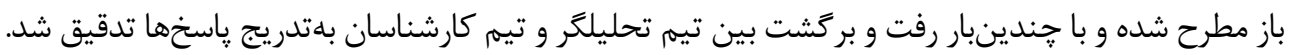

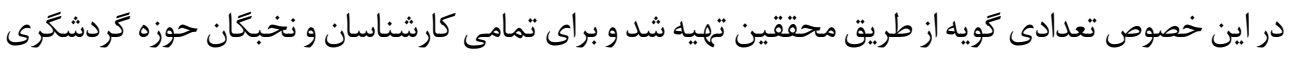

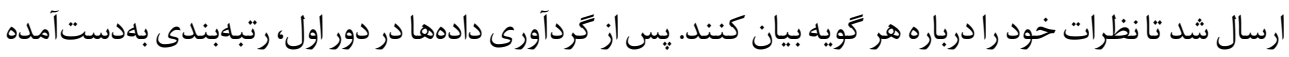

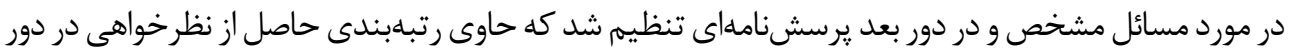

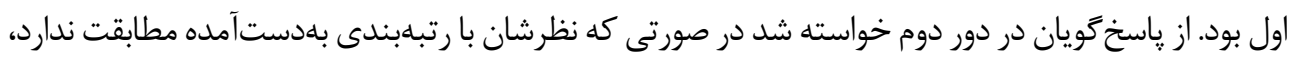

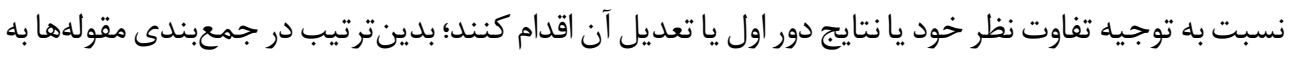

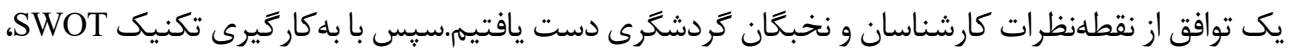

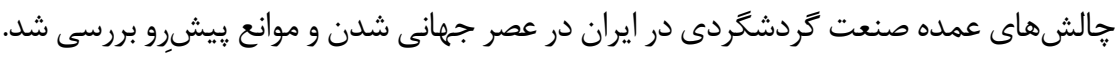

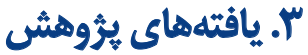

\section{"ا- (ا. تحليل و اوزيابى و عوامل داخلى}

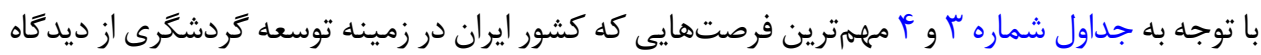

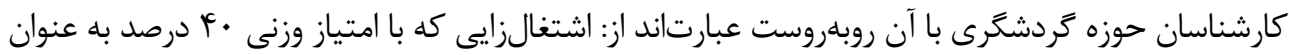

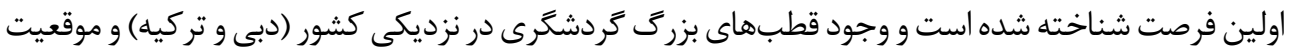

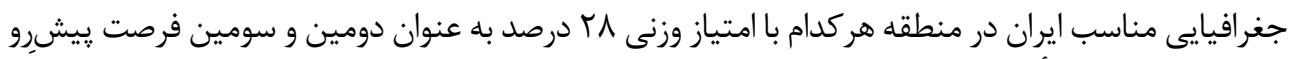

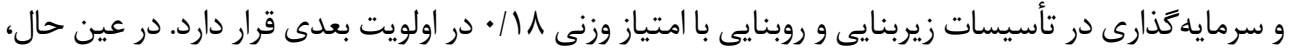

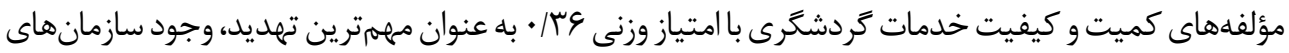

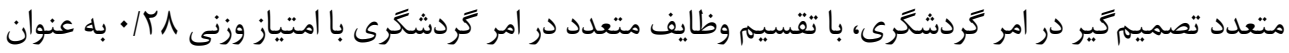


جدول r.نتايج تجزيه و تحليل عوامل خارجى (فرصتها)

\begin{tabular}{|c|c|c|c|}
\hline \multicolumn{3}{|c|}{ كارشيناسان حوزه كردشيكرى } & \multirow[b]{2}{*}{ فروتها| } \\
\hline وزنياز & موجيازوضع & وزن & \\
\hline$\cdot / r$ & fer &.$/ 1$ & 1ـ انشثفال زايع و ايجاد درآمد براي كشور \\
\hline.$/ 14$ & $r$ & $.1 \cdot P^{2}$ & r. افزايش انكيزه بخش خصوصى به سرمايه كذارى در بخش كردشكرى \\
\hline.$/ \mathrm{HA}$ & f & $.1 \cdot v$ & "ا. وجود قطبهاي بزرى كردشكرى در ئزيكي كشور \\
\hline .1 .9 & $r$ & / & f. أقزايش انكيزه بيشتر براى مسافرت و تفريح در بين مردم جهان \\
\hline .1 .8 & $r$ & $\bullet \cdot r$ & هـ اقزايش شمار كردشكران نسبت به سال هاي كذنشته \\
\hline.$/ 10$ & $r$ & $.1 \cdot \Delta$ & و مهتر شلن وضعيت اقتصادى مردم نسبت به دهdهاى كذشته \\
\hline .1 .8 & $r$ & $+1 \cdot r$ & ل. افزايش توجه دولت به سرمايهكذارى در بخش كردشكرى \\
\hline$\cdot / \mathrm{H}$ & $\varphi$ & $+1 \cdot v$ & A موقعيت جغرافيايى مناسب ايران در منطقه \\
\hline$+M$ & $r$ & .1 .8 & 9. سرمايهكثارى در ثأسيسات زيربنايع و روبنايي \\
\hline$+/ \mathrm{M}$ & $r$ & $.1 \cdot v$ & • 1. استفاده از بازار تجارت الكترونيكى و شبكههاى ماهوارهاى به منظور بازار يابى . \\
\hline + & 1 & 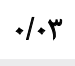 & II. وجود حس مهمان نوازى هردم كشور ايران \\
\hline VIF & & $\cdot / \Delta A$ & جمع \\
\hline
\end{tabular}

دومين عامل و تخريب و بروز خسارت به آثار تاريخى و طبيعى با امتياز وزنى 1/ / • به عنوان سومين عامل و

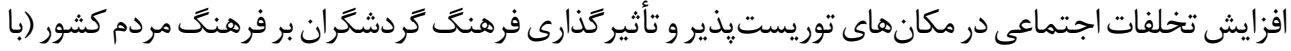

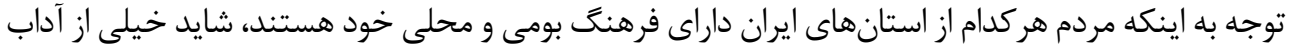

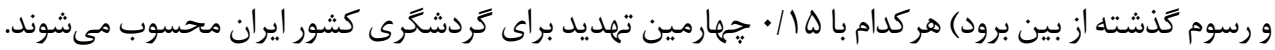
همجنين تحليل SWOT نشان مىدهد كه از ديد

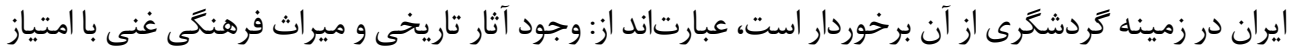

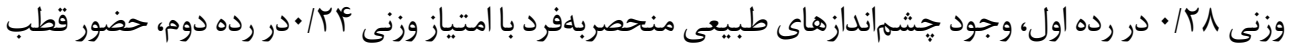

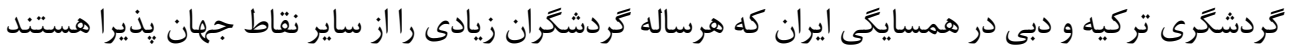

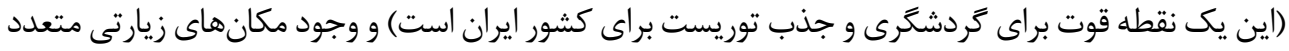

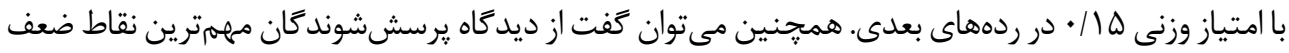

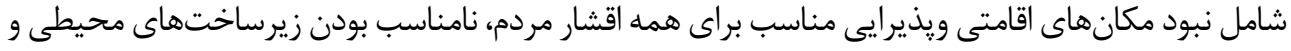

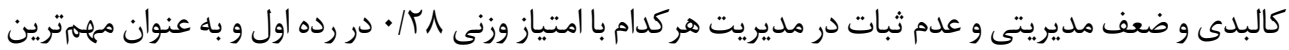


جدول F. نتايج تجزيه و تحليل عوامل خارجى (تهديدها)

\begin{tabular}{|c|c|c|c|}
\hline \multicolumn{3}{|c|}{ كارشيناسان حوزه كردشكرى } & \multirow[b]{2}{*}{ تهديدها } \\
\hline 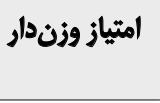 & موجيازوضع & 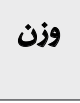 & \\
\hline.$/ M$ & $r$ & .1 .8 & 1. خطر خسارت به آثار تاريخمي، فرهنكى و طبيعى \\
\hline.$/ 18$ & f & .1 .9 & r. كيفيت وكميت خدمات كردشكرى در سطح كشور \\
\hline $.1 \cdot f$ & $r$ &.$/ . r$ & "ا. دمركوني در فرهنى و ساختار جاهعه \\
\hline .110 & r & $.1 \cdot 0$ & F. افزايش تخلفات اجتماعى با ورود كردشكران به سايتهاي كردشكرى \\
\hline.$/ 10$ & $r$ & $.1 \circ \Delta$ & هـ تأثير كذارى فرهنى كردشكران خارجى بر فرهنى هردم ايران \\
\hline.$/ M r$ & $r$ & $* 1+r$ & و هيراكنش ثامناسب فصلى بازديدكندكان خارجى از كشور \\
\hline.$/ 4 A$ & r & 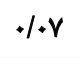 & V. وجود سازمان هاي مثعلد مسئول تصميمكير در امر كردشكرى با تقسيم وظايف متعلد \\
\hline.$/ M r$ & $r$ & 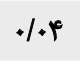 & 1 بودجه تخصيصى دولت به امر تحقيق و ثونسع كردشكرى \\
\hline.$/ M$ & r & .1 .8 & ج. أزايش قيمت كالا و خدمات با افزايش ورود كردشكران خارجى به كشور \\
\hline.$/ 1 r$ & r & $.1+f^{2}$ & . أ ألود5ى هاى محيط زيست \\
\hline .118 & f & .1 .4 & 11. نامناسب بودن و كيفيت بإيين خدمات حملونقل هوائي \\
\hline r & &.$/ 19$ & 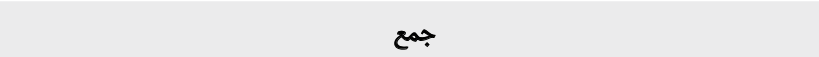 \\
\hline
\end{tabular}

نقاط ضعف كردشكرى كشور ايران شناخته مىشوند و نامناسب بودن راههاى ارتباطى بين شهرها و جاذبههاى

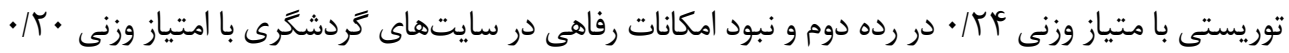
در رده سوم قرار دارند.

در تصوير شماره أ، با استفاده از ماتريس عوامل داخلى و خارجى و استقرار نمرات ماتريسهاى ارئ ارزيابى عوامل

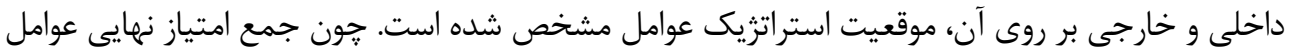

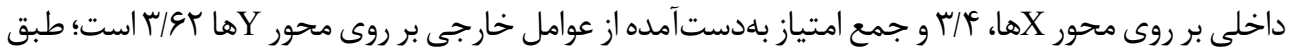

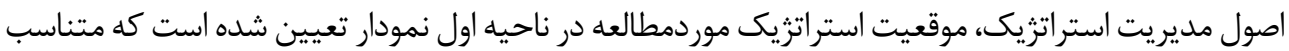
با آن، استراترىهاى تهاجمى (SO) انتخاب خواهند شدوند

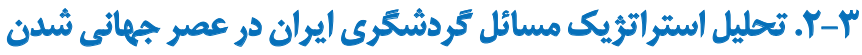
در راستاى تجزيه و تحليل موضوع، در اين يزوهش از مدل مديريت استراتزيك SWOT استفاده شده است. 
جدول هـ نتايج تجزيه و تحليل عوامل داخلى (نقاط قوت)

\begin{tabular}{|c|c|c|c|}
\hline \multicolumn{3}{|c|}{ كارشناسان حوزه كردشيكرى } & \multirow{2}{*}{ نقاط قوت } \\
\hline امثياز وزندار & 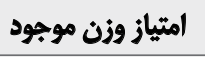 & 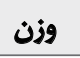 & \\
\hline.$/ \mathrm{KA}$ & r & $+/+V$ & ا. وجود أثار تاريخحى وميراث فرهنكى غنى در مناطق مختلف كشور \\
\hline$\circ \cdot 1$ & r & $1+4$ & r. تنوع آببوهوايى در فصول مختلف سال \\
\hline.$/ \pi f$ & r & 1.9 & "ا. وجود جشماندازهاى طييعى منحصربهفرد \\
\hline 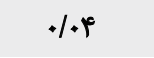 & r &.$/ 4$ & Fا. مستعد بودن منطقه جهت سرمايهكذارى و برنامهريزى كردشكرى \\
\hline.$/ 1 r$ & r & .1 .4 & هـ. وجود صنايع دستى متنوع در مناطق مختلف ايران به عنوان سوغات براي \\
\hline.$/ \mathrm{r}$ & $r$ &.$/ \circ$ & و وجود آداب و رسوم و فرهنى محلى \\
\hline.$/ 4$ & f & $.1 \circ \Delta$ & V. نزديكي قطب كردشكرى تركيه ودبي در همسايكى ايران \\
\hline .1 .8 & r & $\cdot / \cdot r$ & ه داشتن محيط آرام وبدون سروصدا به خصوص براي كردشكران ميان سال \\
\hline$\cdot 1 \cdot r$ & 1 & 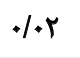 & 9. فقدان محلوديت زمين جهت استفاده توريستي \\
\hline.$/ \mathrm{r}$ & r & $+1+4$ & • +1. وجود حس مهمان نوازى در مردم ايران \\
\hline .110 & $r$ & $+\infty$ & II. وجود مكان هاى زيارتى متعدد براى زيارت كردشكران شيعه مذهب \\
\hline $1 / 4 \pi$ & & $+/ 4$ & \\
\hline
\end{tabular}

در اين الكو با شناسايى دقيق نقاط قوت و ضعف (عوامل درونى) و شناسايى فرصتها و و تهديدات آندات آن (عوامل

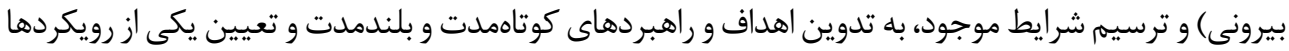

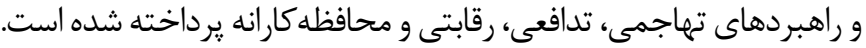

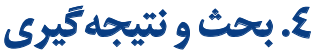

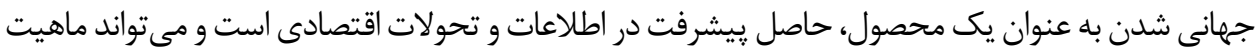

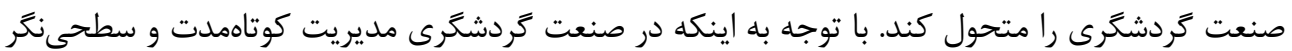

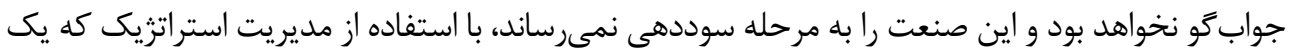

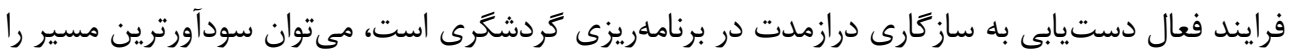

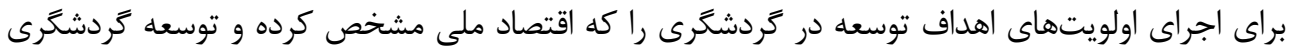

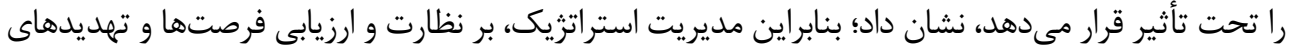

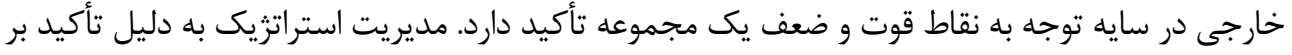


جدول و. نتايج تجزيه و تحليل عوامل داخلى (نقاط ضعف)

كارشيناسان حوزه كردششكيرى

\begin{tabular}{|c|c|c|c|}
\hline 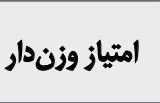 & ا مثياز وزن & 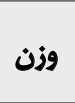 & نقاط ضعف \\
\hline.$/ 4$ & e & .1 .8 & 1. نامناسي بودن راههاي ارتباطي بين شهرها و جاذبههاي توريستي \\
\hline.$/ \mathrm{rA}$ & f & $.1 \cdot v$ & r. كمبود مكان هاي اقاهتى مناسب براى همه كردشكران در مقايسه با استانداردهاي \\
\hline.$/ 4$. & r & .1 .0 & ". نامناسب بودن زيرساختهاى محيطى و كالبدى \\
\hline.$/ 1 r$ & $r$ & $.1 \cdot f$ & f. كميود تسهيلات بهدائتى، درماني و خلماتئ \\
\hline .1 .8 & r & $.1 \cdot \varphi^{+}$ & هـ فقدان حيات شبانه در كانونهاى جمعيتى و كردشكرى \\
\hline$+/ 10$ & $r$ & $\circ 1+\infty$ & ع عدم هماهنكى بين سازمانهاى مرتبط در زمينه كردشكرى و با مردم \\
\hline$+/ 4$ & r & $.1+f$ & V. ضعف تبليغات \\
\hline 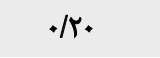 & f & $.1 \cdot \Delta$ & ᄉ نبود امكانات رفاهى در سايتهاى كردشكرى \\
\hline$\cdot / \mathrm{rA}$ & f & $\cdot 1 \cdot v$ & 9. ضعف مديريتى و فقدان ثبات هديريتى \\
\hline .1 .8 & r & $\cdot 1 \cdot r$ & •1. نظارت ضعيف بر عملكرد واحلهاي ارائهدهنده خدمات كردشكرى \\
\hline .1 .8 & r & $\cdot 1 \cdot r$ & ||. عدم سرمايه كذارى بخش دولئى به ميزان لازم \\
\hline.$/ M r$ & r & $.1 \cdot \varphi^{8}$ & rا. عدم وجود نيروهاي هثخصص و آموزشديله در سازمانهاي هرتبط با كردشكرى \\
\hline 1/9Y & & 18. & 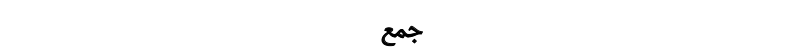 \\
\hline
\end{tabular}

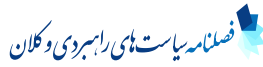

تعيين اهداف، شناسايى نقاط قوت و ضعف، فرصتها و تهديدات خارجى و جشمنداز استقرار بهينه نيروها براى

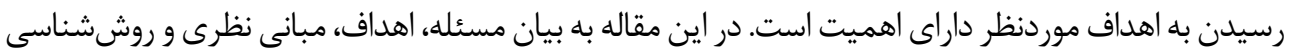

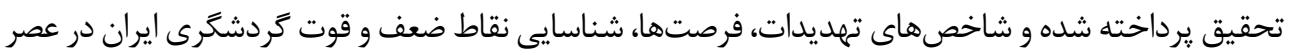

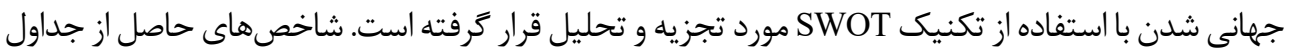

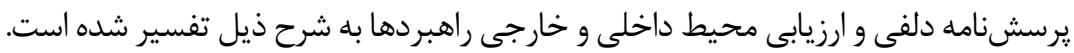

ع-1 ـ تجزيه و تحطليل عواهل استراتثى

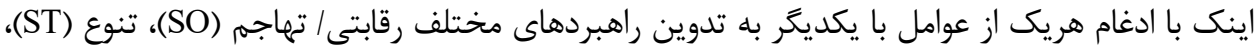

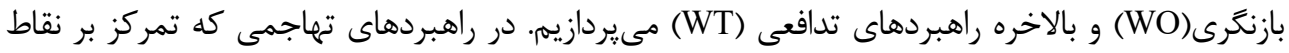

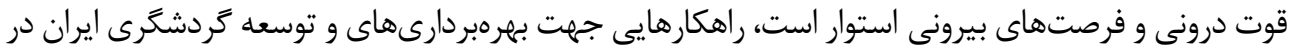




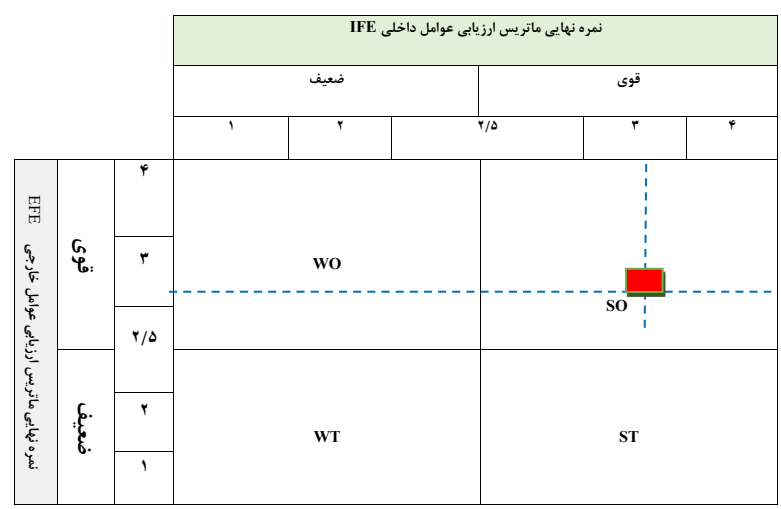

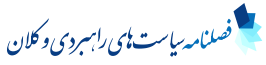

SWOT تصوير f. ماتريس استراترىها و اولويتهاي اجرايى

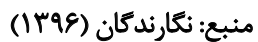

جدول V. ماتريس راهبردها و راهكارهاي توسعه كردشكرى ايران در عصر جهاني شدن

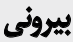

دوبى

تهيليها:

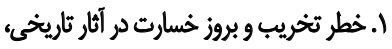

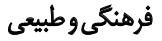

r.كيفيت و كميت خدمات كرششكرى در سطح

$$
\text { كشيور }
$$

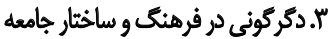

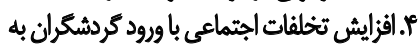

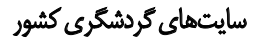

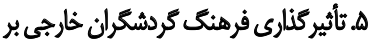

$$
\text { فرنيك مردم ايران }
$$

ويراكنش نامناسب فصلى بازديدكندأن خارجى

$$
\text { از كشور }
$$

V. وجود سازمان هاى متعلد مسئول تصميمكير در

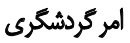

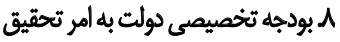

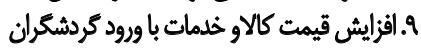

$$
\text { خارجى بله كشور }
$$

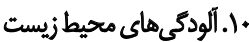

11 . نامناسب بودن و يفيت يإيين خدمات حملونتملهوائي

$$
\text { فربتها: }
$$

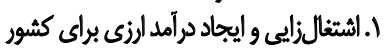

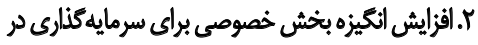

$$
\text { بخش كردنشئرى }
$$

". وجود قطب بيرزى كردشكرى تركيه و دبي در همسايكي

$$
\text { كشور اليران }
$$

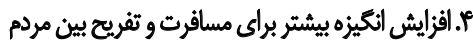

$$
\text { كشورهاى جهان }
$$

هـ افزايش شمار كردشكران نسبت بله سال هاي كأشته

$$
\text { هرجهان }
$$

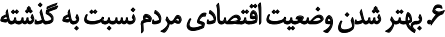

V. أززايش توجه دولت به سرمايه كثاري در بخش

$$
\text { كرشئرى }
$$

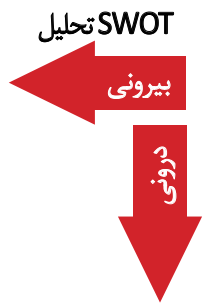

A. موقعيت جغرافيايي مناسب إيران مر منطقه

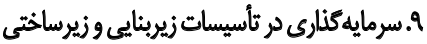

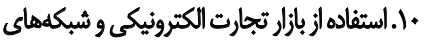

ماهوارهاي به منظور بازاز إيائي المتروئيكي

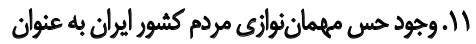

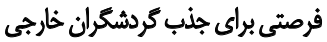


استراتثوى هاى WO

1.

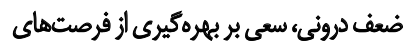

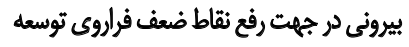

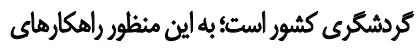

$$
\text { زير ارائه مي شودود: }
$$

r. باززنكرى در توزيع امكانات وخدمات كردشكى

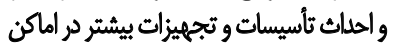
كرشكرى براي جلب كرشكران خارجي

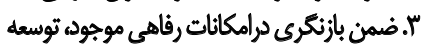

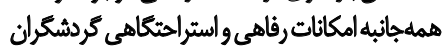
خارجى مورد توجه قرار كيرد

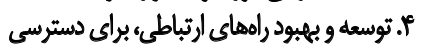
أسانتر وكهزئنهرتركرشكران به سايتهائى كرشكرى هـ بهيبودو ارتقاى محصولات كردشكرى (علمى،

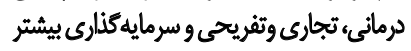

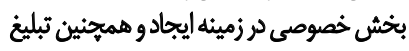
زيرساختها و محصولات كردشكرى كثور به به كرئشران؛

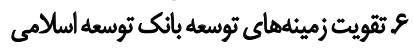

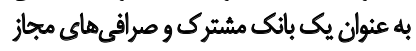

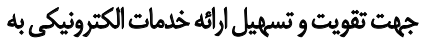
كرششكران

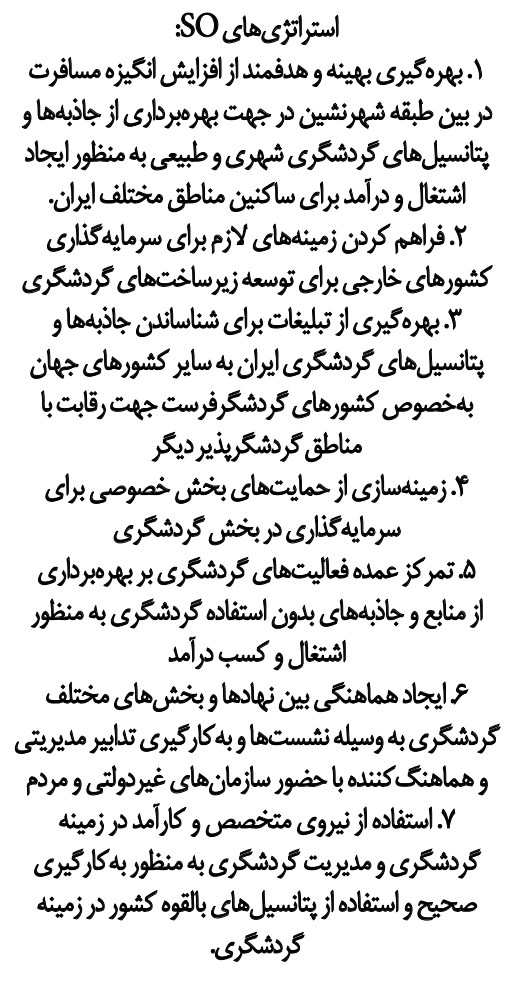

نقاطقوت:

1. ا.وجود آثار تاريخى وميراث

فرهنكى غنى در مناطق مختلف كشور ايران

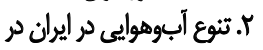

فصول مختلف سال

"الم. مستعد بودن كشور ايران

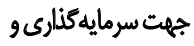

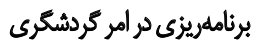

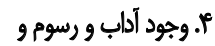

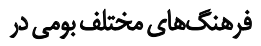

مناطق مختلف كشور

هـ وجود صنايع دستى متنوعرد مناطق مختلف ايران به عنوان سوغات براى خريد كرشكران

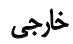

و وجود جشمهانثازهاي طبيعى زيبادر مناطق مختلف كشوري V.نزئزيكى قطب تردشكرى تركيه درمسايكى ايراني لـ داششن محيط آرام و بلدون

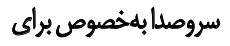
كردشكران ميانسال به بالاكه جوياي محيطى آرام هستند 9. فقلان محلوديت زمين جهت الهنت

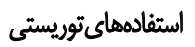
•. 1. وجودمكان هانى زيارتى متعددراى زيارت كرشكران شيعلهنب 


\begin{tabular}{|c|c|c|}
\hline & بيرونج & درونى \\
\hline 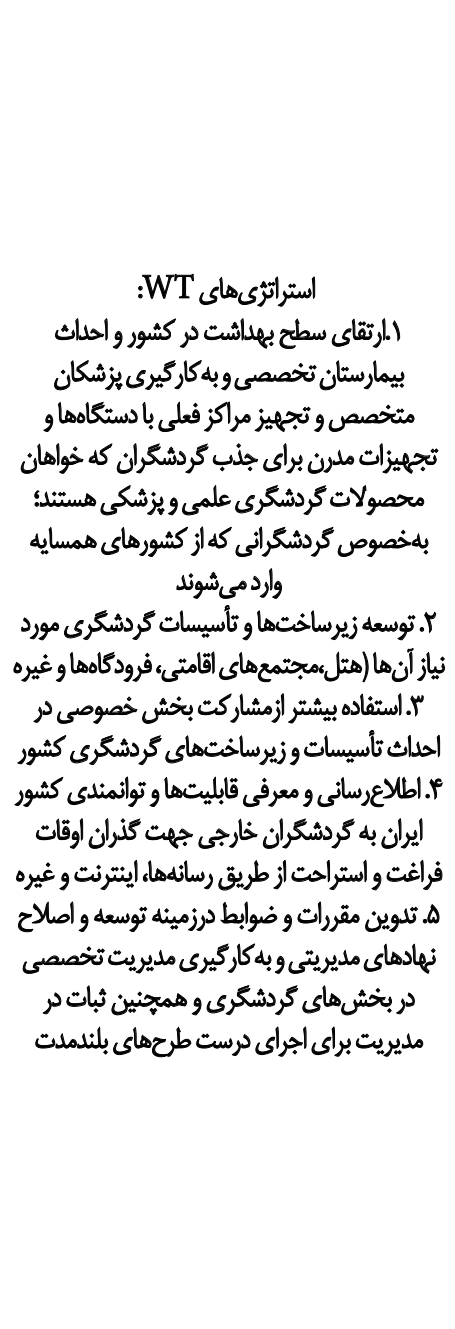 & 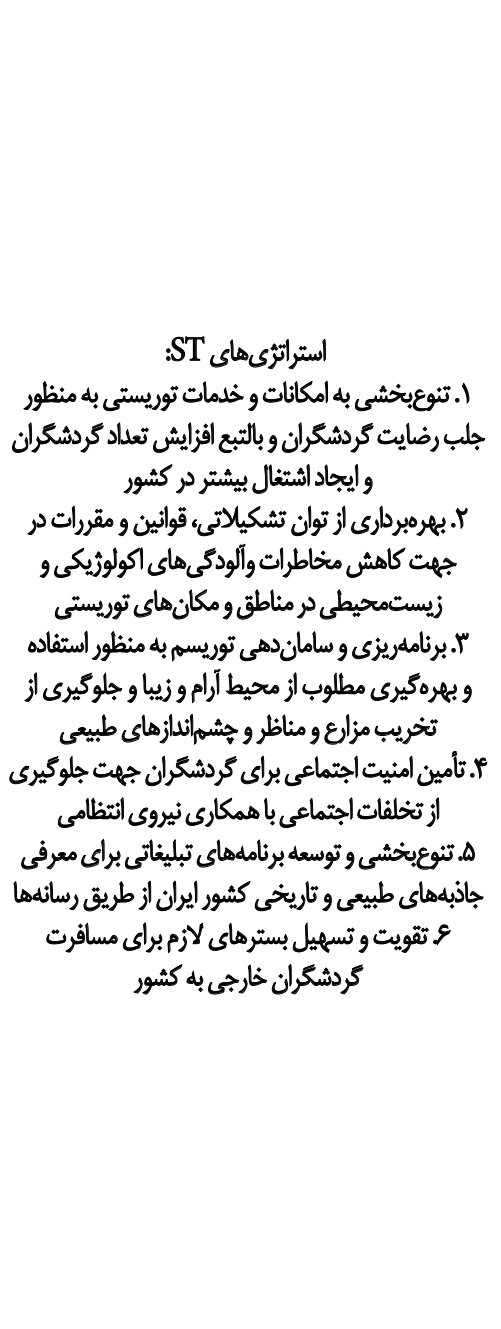 & 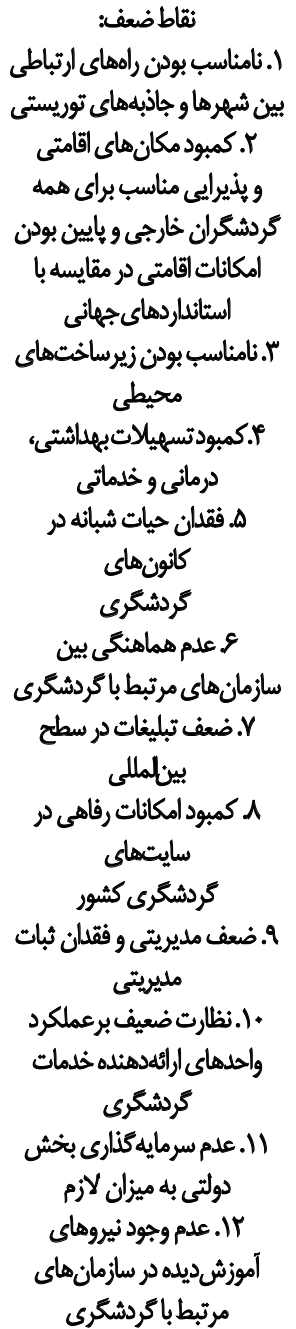 \\
\hline
\end{tabular}




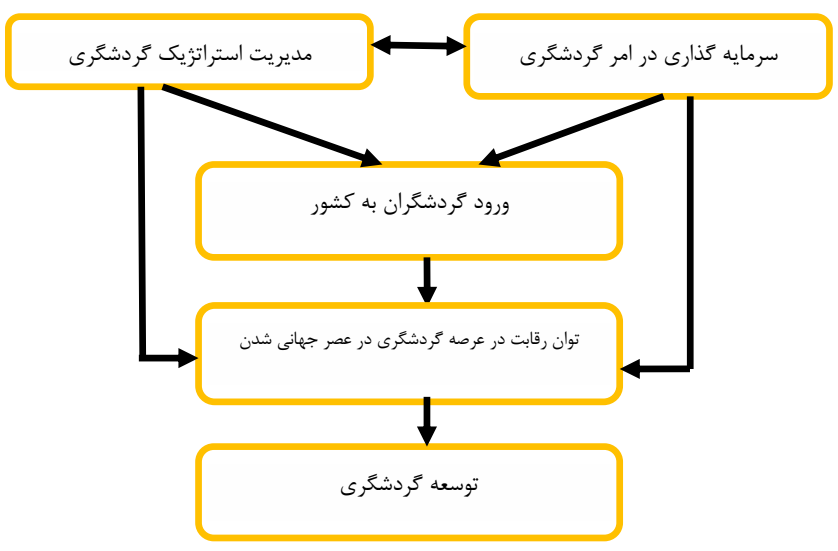

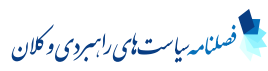
تصوير ه. مدل روند توسعه كردشكرى در عصر جهانى شدن در كشور تهيه كنيده: نكارندكان

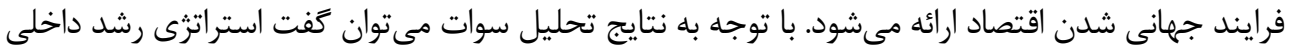

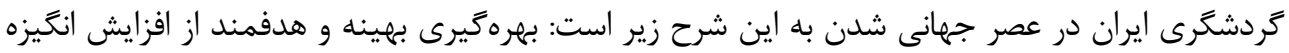

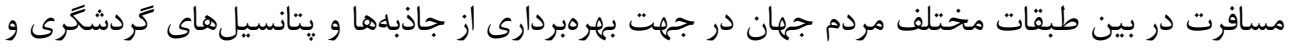

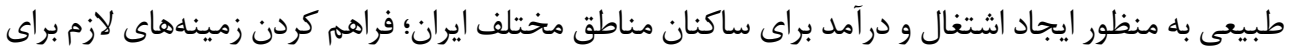

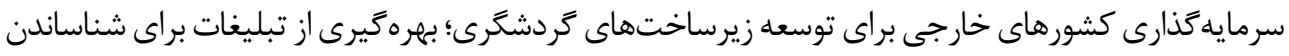

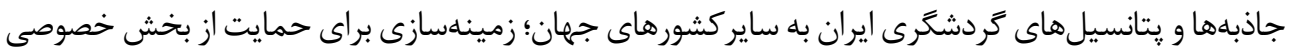

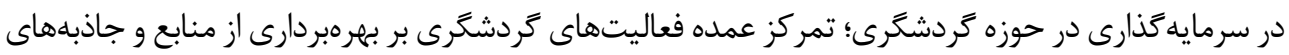

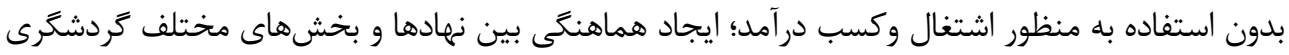

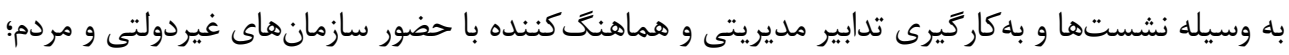

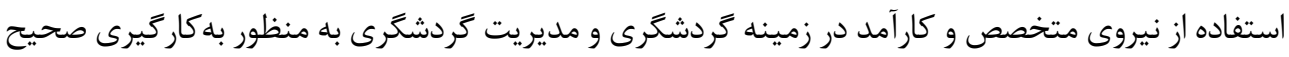

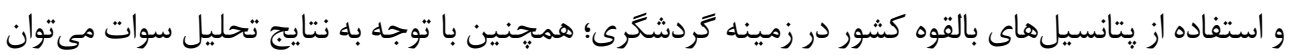

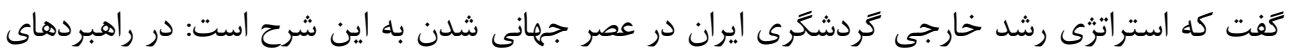

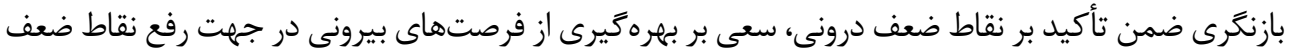

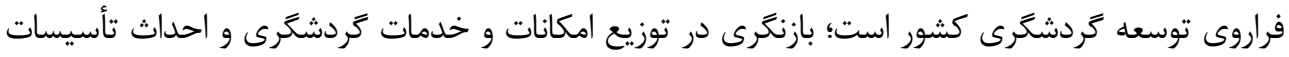

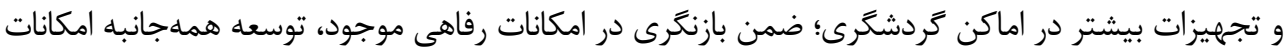

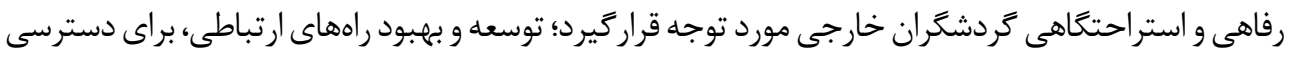

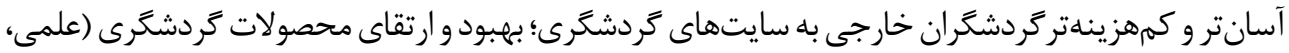

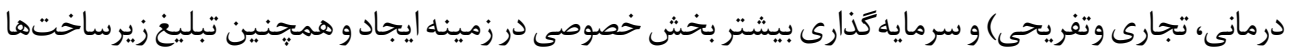


و محصولات كردشگرى كشور به گردشگران؛ تقويت زمينههاى رشد بانك توسعه اسلامى به عنوان يك بانك

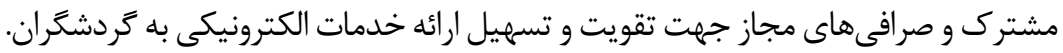

استراترى حداقل رساندن نقاط ضعف گردشخرى ايران در عصر جهانى شدن به اين شرح هستند: تنوعبخشى

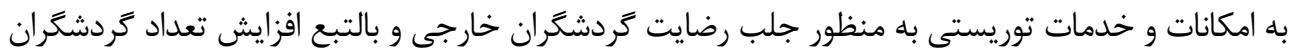

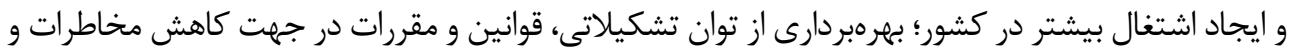

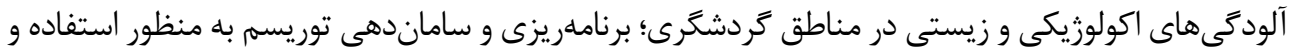

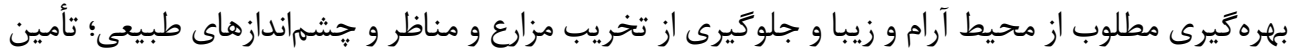

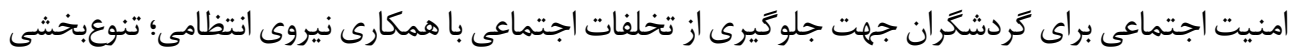

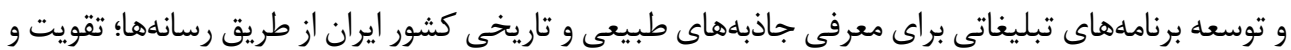

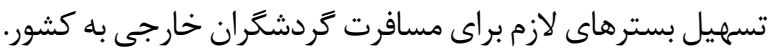

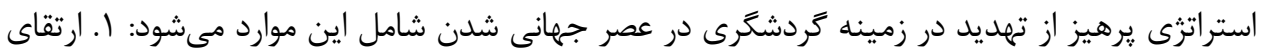

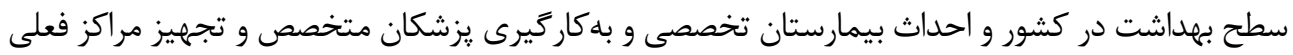

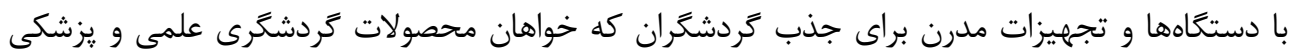

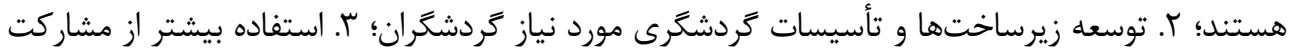

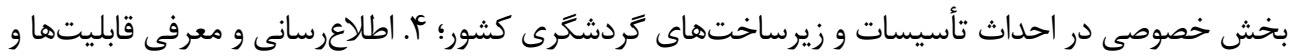

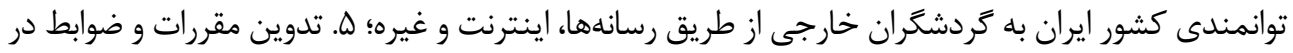

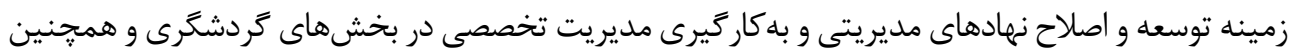

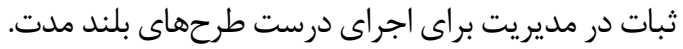

موقعيت جغرافيايى ايران ميىتواند به عنوان يك مزيت مهرم در رقابت جهانى گردشخرى مورد استفاده و

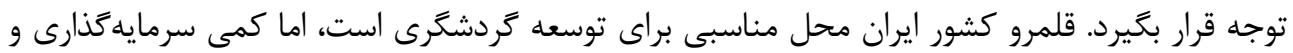

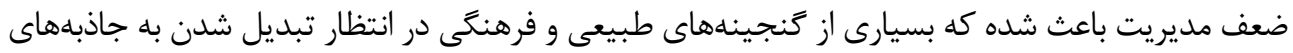

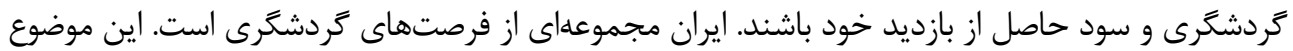

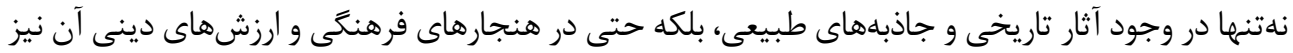

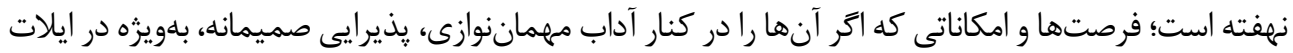

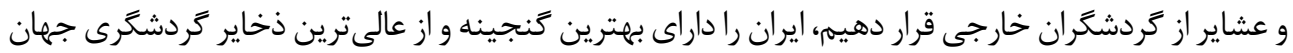

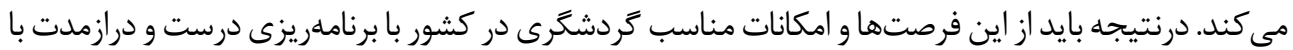

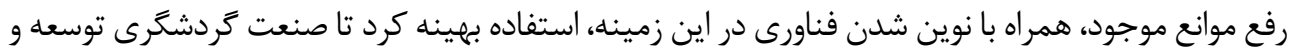

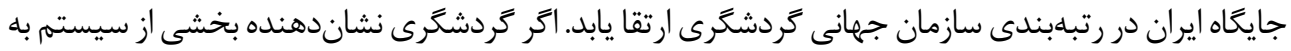

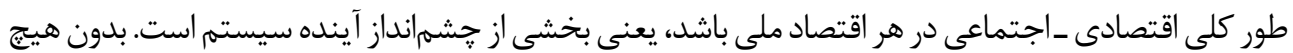

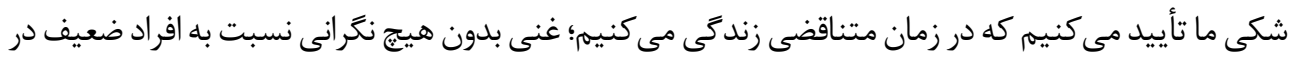

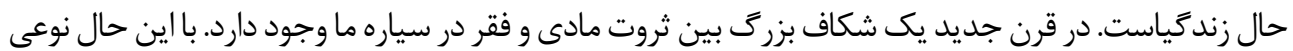




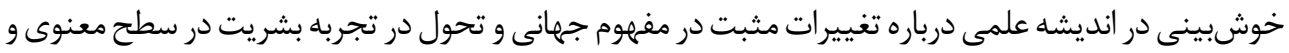

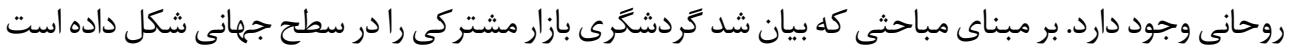

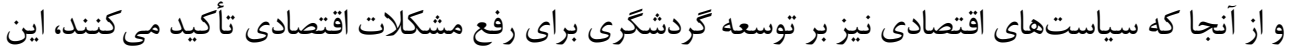

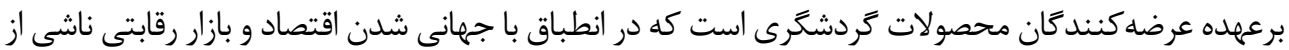

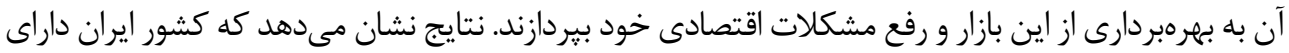

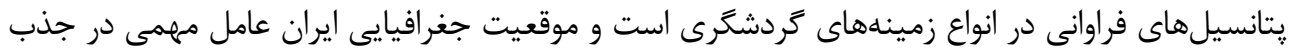

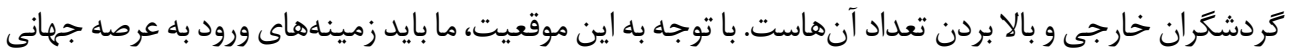

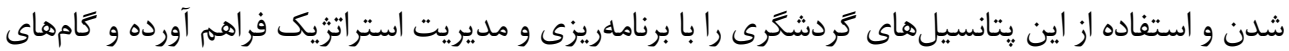

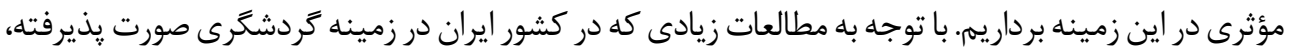

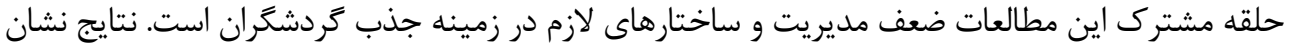

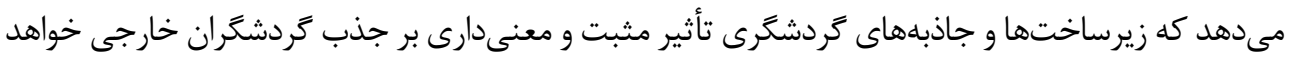

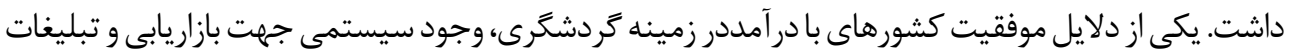

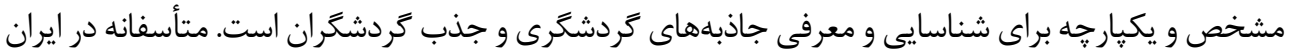

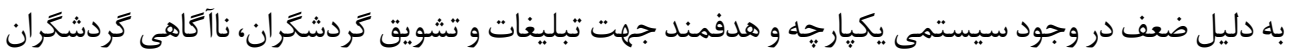

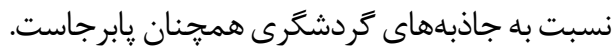

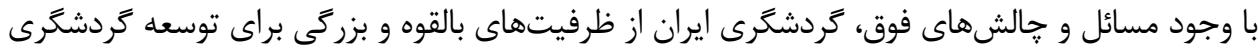

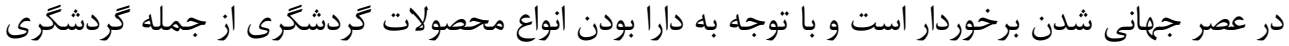

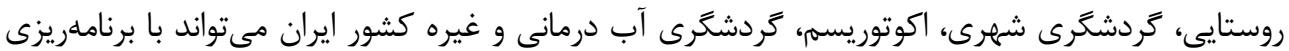

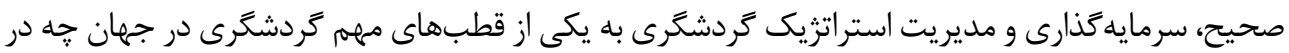

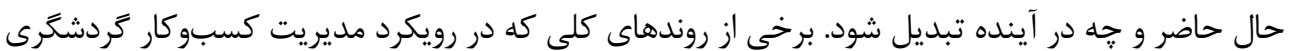

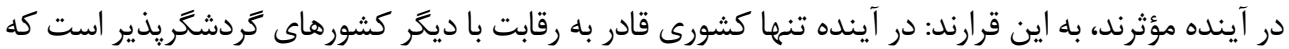

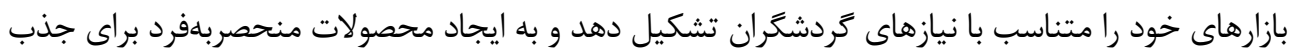

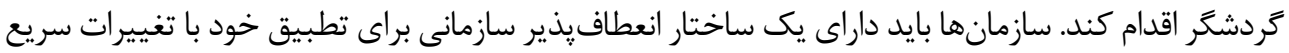

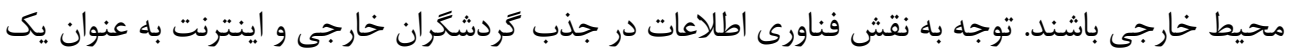

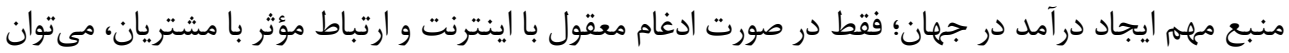

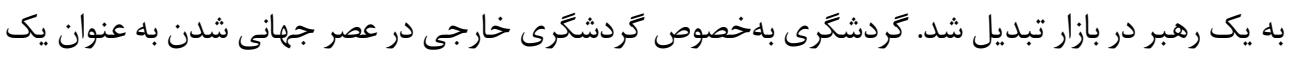

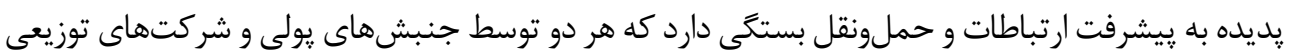

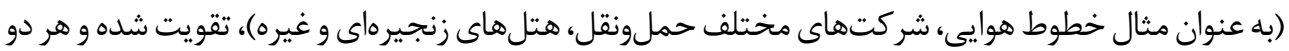

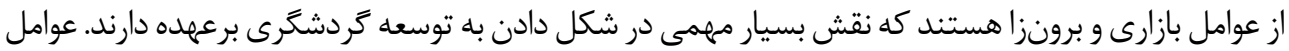

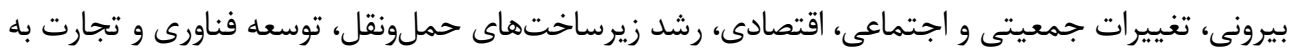

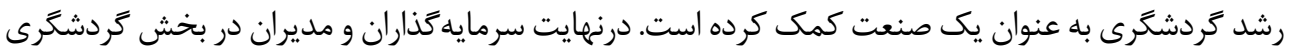

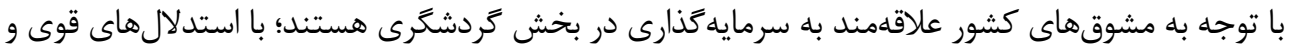


معتبر و ارائه مشوقهاى اقتصادى به آنان و ايجاد اطمينان از سود حاصل از سرمايهَذارى در بخش گردشگرى

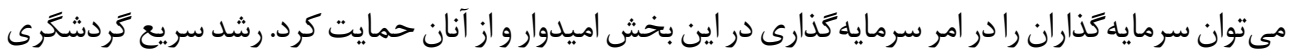

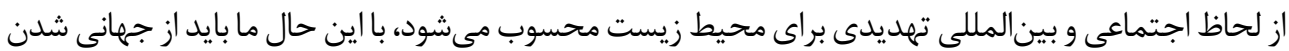

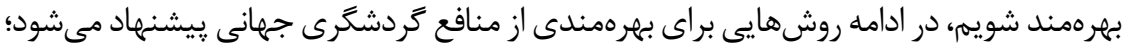
توسعه آموزش نيروى انسانى به ويثزه راهنمايان تور متخصص و زبده در بخش هاى مختلف كردشگرى؛ توجه

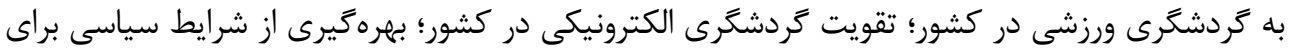

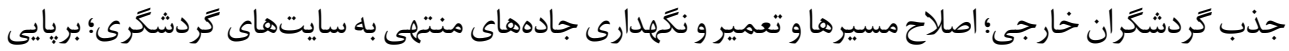

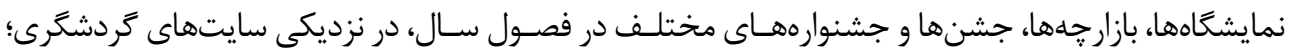

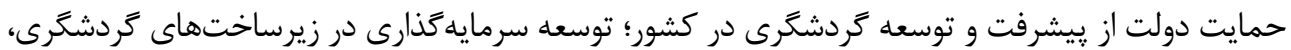

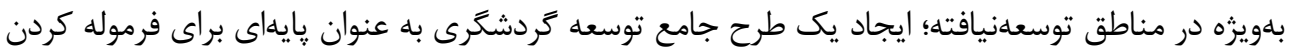

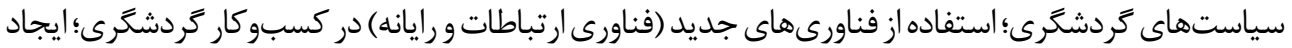

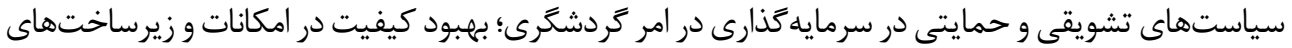

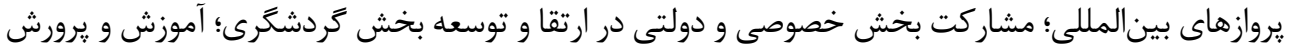
نيروى كار براى دستيابى به مزيت رقابتى.

در فرايند برنامهريزى بايد دو سطح بخش دولتى و بخش خصوصى با هم همكارى داشته باشند؛ جون

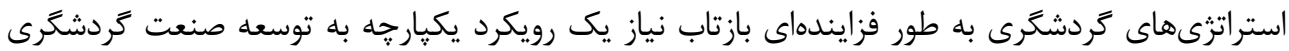

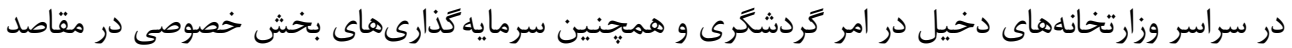

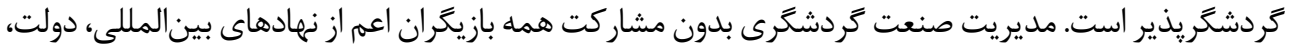
بخش خصوصى و حتى مردم امرى غيرممكن است.

ملاحظات اخلاقى

\section{يبروى از اصول الخالق يُوهش}

همه اصول اخلاقى در اين مقاله رعايت شده است. شركت كنند

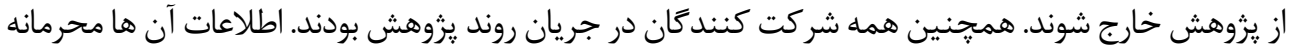

نحه داشته شد.

حامي مالى

اين يزوهش هيجگَّنه كمك مالى از سازمانيهاى دولتى، خصوصى و غير انتفاعى دريافت نكرده است. 


$$
\text { مشار كث نويسند }
$$

تمام نويسندگان در آمادهسازى اين مقاله مشاركت داشتهاند.

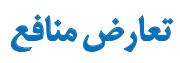

بنابر اظهار نويسندگان، اين مقاله تعارض منافع ندارد. 


\section{References}

Amaldas, M. (2009). The management of globalization in Singapore: Twentieth century lessons for the early decades of the new century. Journal of Alternative Perspectives in the Social Sciences, 1(3),982-1002. http://journaldatabase.info/articles/management_globalization_singapore.html

Azarya, V. (2004). Globalization and international tourism in developing countries: Marginality as a commercial commodity. Current Sociology, 52(6), 949-67. [DOI:10.1177/0011392104046617]

Buhalis, D., \& Law, R. (2008). Progress in information technology and tourism management: 20 years on and 10 years after the Internet - the state of eTourism research. Tourism Management, 29(4), 609-23. [DOI:10.1016/j. tourman.2008.01.005]

Choi, H. S. Ch., \& Sirakaya, E. (2006). Sustainability indicators for managing community tourism. Tourism Management, 27(6), 1274-89. [DOI:10.1016/j.tourman.2005.05.018]

David, F. R. (2017). Strategic management [M. Arabi, \& M. Taghizadeh Motlagh, Persian Trans]. Tehran: Iran Cultural Studies.

Dwyer, L., Edwards, D., Mistilis, N., Roman, C., \& Scott, N. (2009). Destination and enterprise management for a tourism future. Tourism Management, 30(1), 63-74. [DOI:10.1016/j.tourman.2008.04.002]

Esmaeilzadeh, H., Sarrafi, M., \& Tavakkolinia, J. (2012). [Analysing tourism development approaches in local communities (Persian)]. Environmental Sciences, 9(2), 119-42. https://www.sid.ir/fa/journal/ViewPaper.aspx?id $=157237$

Feige, M. (1998). Tourism at the beginning of the new millennium. Tourism, 48(2), 101-4. https://www.cabdirect.org/ cabdirect/abstract/20003004613

Hociung, I. G., \& Francu, L. G. (2012). Globalization - tourism - communication, competitiveness triangle on the market affected by the economic crisis. Theoretical and Applied Economics, 7(572), 133-46. https://bit.ly/3frVKEM

Khanzadi, A., Falahati, A., \& Heirani, Z. (2018). [Investigating and analyzing the role and effects of tourism development on income distribution in the provinces of Iran (Persian)]. Journal of Tourism and Development, 7(1), 84-100. http://www.itsairanj.ir/article_63613.html

Kirovska, Z. (2011). Strategic management within the tourism and the world globalization. Journal of Economics, 2(1), 69-76. https://ideas.repec.org/a/ris/utmsje/0028.html

Lanquar, R. (2007). Tourism, migrations and co-development. International Journal of Sociology, 65(48), $221-41$. [DOI:10.3989/ris.2007.i48.75]

Lotfi, H., Soltani, N., \& Eghbali, N. (2009). [Tourism, government and political economy in Iran (Persian)]. Journal of Studies of Human Settlement Planning, 3(7), 87-110. http://jshsp.iaurasht.ac.ir/article_522377.html

Marin, S. C. (2016). Strategic management in public administration. Paper presented at International Conference "Risk in Contemporary Economy", Galati, Romania, 2016. https://pdfs.semanticscholar.org/7870/ebff92f239b9e7a799de7846c9eee2111e84.pdf

Modest, D. B. (2009). Stages and effects of globalization. Acta Universitatis Danubiu, 2(1), 110-24. http://journals. univ-danubius.ro/index.php/internationalis/article/view/1479 
Mohamadzadeh, P., \& Samadzad, S. (2018). [The factors affecting the formation of the destination image from the domestic tourists' perspectivetourism management studies (Persian)]. Tourism Management Studies, 13(41), 83107. [DOI:10.22054/tms.2018.18306.1507]

Mohammadfam, I. (2008). [Strategic management based safety: Why and how? (Persian)]. Iran Occupational Health, 5 (1-2), 1-5. http://ioh.iums.ac.ir/article-1-112-fa.html

Mohseni, R. A. (2010). [Sustainable tourism in Iran: Functions, challenges and solutions (Persian)]. Geographic Space, 9(28), 149-71. https://www.sid.ir/fa/Journal/ViewPaper.aspx?id=102424

Monavvarian, A., Aghazade, H., \& Shahamatnejad, M. (2012). [Measuring the strategic thinking of the managers of Tehran's municipality (Persian)]. Journal of Business Management, 4(2), 129-46. [DOI:10.22059/jibm.2012.29187]

Mowlana, H., \& Smith, G. (1993). Tourism in a global context: The case of frequent traveler programs. Journal of Travel Research, 31(3), 20-7. [DOI:10.1177/004728759303100304]

Naghibossadat, S. R. (2003). [Globalization (Persian)]. 1 ${ }^{\text {st }}$ Ed. Tehran: Ketabe Sobh. http://opac.nlai.ir/opac-prod/ bibliographic/685891

OECD. (2010). Tourism 2020: Policies to promote competitive and sustainable tourism. Retrieved from https://bit. ly/2YCNdrB

Osborne, D., \& Gaebler, T. (1993). Reinventing government: How the entrepreneurial spirit is transforming the public sector. London: Plume. https://books.google.com/books?id=7qyp_EcJuZoC\&dq

Papoli Yazdi, M. H., \& Saqai, M. (2009). [Tourism (nature \& concepts) (Persian)]. $3^{\text {rd }}$ Ed. Tehran: SAMT. http://opac. nlai.ir/opac-prod/bibliographic/1876076

Peric, V. (2005). Tourism and globalization. Paper presented at the $6^{\text {th }}$ International Conference of the Faculty of Management Koper, Congress Centre Bernardin, Slovenia, Balkans, 24-26 November 2005. http://www.fm-kp.si/ zalozba/ISBN/961-6573-03-9/peric.pdf

Petrevska, B. (2012). Forecasting international tourism demand: The evidence of macedonia. UTMS Journal of Economics, 3(1), 45-55. [DOI:10.7251/ZREFIS1307051P]

Quian, Sh. (2010). Research on behaviors of govwrment's tourism marketing. UTMS Journal of Economics, 1(1), 99-106. https://ideas.repec.org/a/ris/utmsje/0009.html

Radulovic, L. (2013). The role and potential of global distribution system amadeus for tourism development at the global level. Singidunum Journal, 10(1), 28-38 [DOI:10.5937/sjas1301028R]

Ritchie, B. W. (2004). Chaos, crises and disasters: A strategic approach to crisis management in the tourism industry. Tourism Management, 25(6), 669-83 [DOI:10.1016/j.tourman.2003.09.004]

Seyed Alipoor, S. K., Eghbali, N., Bakhshande Nosrat, A. (2010). [Tourism management and its role in rural development case study: Villages of semnan province (Persian)]. Journal of Industrial Strategic Management (Pajouheshgar), 7(19), 52-69. https://www.sid.ir/fa/journal/ViewPaper.aspx?id=124662

Stiglitz, J. E. (2006). Making globalization work. New York: Norton. https://books.google.com/books?id=AdHM3 LCNtMC\&dq 
Tabatoni, P., \& Jarniou, P. (1975). [The management systems, policies and structures (Les systèmes de gestion: Politiques et structures) (French)]. Paris : Presses Universitaires de France. https://books.google.com/books?id=52ogPAAACAAJ\&dq

Taj, Sh. (2003). [A model for the development of ecotourism (Persian)]. Daneshnameh, (46-47).

Yaghobipour, M. (2009). [The impact of culture globalization on national identity (Persian)]. Political \& Economic Ettelaat, 24(267-268), 110-21. https://www.magiran.com/paper/701177

Zarei Matin, H., Seyedjavadein, S. R., Rahimpour, A., \& Bagheri, M. (2012). [Explaining I.R. of Iran's tourism industry challenges (Persian)]. Strategic Management Thought, 6(1), 73-106. http://smt.journals.isu.ac.ir/article_1024. html 